\title{
LOS JUDÍOS EN EL REINO DE VALENCIA. TESTIGOS DE UNA HISTORIA SECULAR
}

\author{
José Hinojosa Montalvo \\ Universidad DE Alicante
}

\begin{abstract}
Resumen: Los judíos valencianos conocieron una compleja y diversa trayectoria histórica durante los siglos bajomedievales marcada siempre por su difícil relación de todo tipo con la comunidad dominante, la cristiana. Los perfiles sociales, las principales actividades y los aspectos de la cultura material y de la vida cotidiana hebrea valenciana se reconstruyen a través de un análisis que descansa en un amplio examen historiográfico y revisión documental.
\end{abstract}

Palabras clave: judíos, conversos, sociedad, actividades, cultura, vida cotidiana, reino de Valencia, baja Edad Media.

Abstract: The Jews from Valencia knew a complex and varied historical course during the late middle age centuries, always marked by its difficult relationship in every sense with the dominant community, the christian one. The social profiles, the main activities and the aspects of the material culture and of the hebrew daily life in Valencia, are reconstructed through an analysis which consists of a broad historiographic examination and documentary checking.

Keywords: Jews, convert, society, activities, culture, daily life, Kingdom of Valencia, late middle ages.

Reconstruir el pasado histórico de los judíos en estas tierras es una tarea ardua, lenta y difícil, ya que las fuentes existentes no se lo ponen fácil al investigador y ni siquiera, como en Sagunto, podemos recurrir a leyendas o tradiciones que nos remonten a la Antigüedad clásica. La riqueza documental es desigual 
según las localidades y nunca remonta el final del siglo xIII, como es el caso de Cocentaina, siendo más abundante a partir de 1370 para el caso de Elche, Orihuela o Alcoi, donde se conservan las actas municipales. Para otras localidades, como Alicante, el vació es total, pues los archivos medievales se perdieron con las guerras y por la desidia de las gentes. Por fortuna para el historiador la documentación conservada, sobre todo, en el Archivo de la Corona de Aragón y en el Archivo del Reino de Valencia suplen parte de las carencias indicadas.

La presencia judía en el reino de Valencia mejor documentada es la que va desde la conquista de Jaime I hasta la expulsión de 1492, con un suceso esencial en el intermedio, que fue el asalto en julio de 1391 a las juderías y la conversión masiva de sus moradores al cristianismo, con lo que a partir de entonces la presencia judía en estas tierras fue muy débil, sustituidos por los conversos de judíos.

\section{UNAS PINCELADAS DE HISTORIA}

Igual que sucedía con los mudéjares, la conquista cristiana marcó una clara ruptura con la anterior etapa andalusí, de la que muy poco sabemos sobre la presencia de judíos en estas comarcas, si se exceptúa Denia, ciudad que fue cabeza de un brillante -sobre todo en lo cultural- reino de taifa durante el siglo XI, en el que tenemos documentada la presencia de judíos, de la que ya me hice eco en mi obra sobre los judíos valencianos. Así, vemos al rabino Isaac ben Mosé ben Sakay, que fue rabino de Denia hasta el año 1070, en que partió a Pumbedita, en la cuenca del Éufrates. Otro rabino fue Isaac ben Rubén, que llegó a Denia procedente de Barcelona para sustituir a Sakay y se convirtió en uno de los primeros traductores de obras árabes al hebreo, siendo también un notable talmudista. Dos datos conviene destacar de cuanto hemos dicho: por un lado, la presencia de estos rabinos, lo cual implica la existencia de un numeroso grupo de fieles, a los que hay que atender espiritualmente, y por otro, la importancia que se concedía a Denia para que venga un rabino desde Barcelona, reflejando así los lazos entre ambas ciudades, que no sólo eran comerciales, sino también espirituales. Recuérdese al respecto que es ahora, en tiempos de Muyahid, cuando éste firma un pacto con el obispo de Barcelona, que extiende su protección religiosa sobre los cristianos residentes en Denia. Hay también algún documento de la Genizah de El Cairo con alusiones a judíos de Denia en estas fechas, algo lógico si tenemos en cuentas los vínculos comerciales que nuestra ciudad mantenía con Egipto en el siglo XI. Ahí están los magníficos candelabros de bronce de los Museos Arqueológicos de Denia y de Alicante para ratificarlo. En cualquier caso, hay que tener presente que los judíos - como los cristianos- tenían la condición de protegidos o dimmis y podían practicar libremente su religión y vivir de acuerdo con sus propias normas, siempre que no atentaran contra el Islam. 
Pero regresemos al siglo XIII y recordemos como el monarca aragonés Jaime I conquistó al Islam las tierras situadas al norte de la frontera Biar, Castalla, Xixona y Busot hasta el mar, según lo estipulado en el tratado de Almizrra (1244), mientras que las que estaban al sur de la citada línea se incorporaron al reino de Murcia, en la corona castellana. Ello provocó que la primera fase de la historia de las comunidades judías en nuestras tierras sea compartida por la de Castilla y Valencia, abarcando el período 1250-1305, en que se incorporaron definitivamente al reino de Valencia. De la anterior etapa nada sabemos y es ahora, a raíz de la conquista cristiana, cuando hay que situar el punto de partida del judaísmo valenciano.

Esta segunda mitad del siglo XIII es una etapa de asentamiento y consolidación de las pequeñas comunidades hebreas en estas tierras, ya que, frente al denso asentamiento musulmán, los judíos siempre fueron escasos en número. Algunos colaboraron con la Corona en la defensa contra los mudéjares alzados en armas, como sucedió en Orihuela en 1264, cuando Jacob Avendino participó activamente con los cristianos en la defensa de la villa, lo que le reportó importantes beneficios económicos, recibiendo un rico patrimonio territorial en la ciudad y su término, en las mejores partidas ${ }^{1}$.

Tanto Jaime I como Alfonso X, con el fin de atraer nuevos pobladores, no hicieron distinción alguna en cuanto a raza y fe se refiere y estimularon la llegada y asentamiento de judíos en sus territorios, a cuyo efecto les hicieron donación de casas, tierras y una extensa gama de privilegios, que los igualaban a sus correligionarios del resto de la Corona de Aragón o de Castilla. Los judíos pasaron a ser uno de los tres pilares sobre los que se cimentaría la sociedad valenciana bajo-medieval, ya que los monarcas no veían en ellos tan sólo al puro repoblador, sino también al comerciante, al conocedor administrativo, de oficios en los que los judíos ya habían adquirido fama durante su estancia en al-Andalus por el hecho de haber ocupado importantes puestos en la administración estatal musulmana, cosa de la que los reyes tenían constancia. La consecuencia inmediata fue doble: por un lado, los cristianos comenzaban a ver con cierto recelo a estos magnates judíos, quienes por gracia del rey tenían una consideración similar a la de los nobles, y que gozaban de un gran poder económico, gozando a veces de inmunidad y de exenciones tributarias; por otro, entre el grueso del pueblo judío (artesanos, etc.) y esta aristocracia judía de cortesanos se abrió un ancho foso, lo cual originó no pocas disputas y enfrentamientos entre los miembros de la comunidad.

1. Vilar, J. B., «La judería medieval de Orihuela (Alicante)», Boletín de la Asociación Española de Orientalistas, año XIII, (1977), pp. 175-186. 
En cualquier caso la política seguida por los reyes nunca estuvo bien vista, y fue criticada por el Pontificado, defensor de los postulados del IV concilio de Letrán (1215). La Monarquía castellano-leonesa estaba protegiendo decididamente a los israelitas, a sus «servi regis». Pero en el contexto europeo, el mencionado concilio tan sólo admitía la presencia judía en los reinos cristianos como testimonio de la Pasión del Señor, ya que los judíos eran considerados como los deicidas, siguiendo la idea de San Agustín, por lo que endureció las medidas de segregación y discriminación contra los judíos, a fin de evitar cualquier contacto con los cristianos. El Papado exigía a los reyes que respetaran tales medidas de exclusión, pero la monarquía, por intereses esencialmente económicos, y pese a su legislación a veces contradictoria, siempre mediatizó la oposición y el odio incipiente del pueblo, y se negó a llevar a la práctica las decisiones de concilios como el de Letrán o el de Vienne de 1311. Recordemos que los judíos en sus asuntos internos, los que afectaban a judíos, se regían por la Ley Mosaica, mientras que en sus relaciones con cristianos y judíos estaban sometidos a la normativa emanada de los Furs de València.

Los judíos valencianos vivieron una época dorada que se prolongó hasta la primera parte del reinado de Pedro III, participando en la tarea repobladora en el reino; fueron arrendadores de impuestos, escribanos, bailes, etc. Sin olvidar su importante labor como intérpretes entre cristianos y moros, como es el caso de Astruc Bonsenyor, que en 1264, actuó como intérprete para la rendición de los mudéjares de Elche, sublevados contra Alfonso X de Castilla. Este judío, bien situado en las relaciones cortesanas, fue uno de los comisionados para repartir tierras del término, junto con otros cristianos.

La política exterior de la monarquía aragonesa iba a tener, sin embargo, consecuencias negativas para los judíos. Con motivo de la conquista de la isla de Sicilia, impulsada por Pedro III surgió un frente opositor integrado por los ricoshombres y las oligarquías urbanas, que consiguieron la promulgación del llamado Privilegio General que prohibía a los judíos el desempeño de cargos públicos en los reinos de Aragón, Valencia, Ribagorza y Teruel. La norma se cumplió y en el futuro ya no habrá judíos cortesanos y los que encontremos en el entorno regio lo serán a título personal, en particular los médicos, traductores, embajadores, financieros, etc., siempre desligados de la actividad política. Era el reflejo del recelo que despertaban los judíos entre los distintos grupos sociales de la sociedad cristiana.

Pero los reyes necesitaban a los hebreos para mantener la actividad económica de los territorios conquistados y así los vemos instalarse en diversas localidades por los reinos de Valencia y Murcia, en aquellas que poseían un claro valor estratégico o comercial -en algunos casos ello estuvo en función de la guerra contra los musulmanes sublevados con Al-Azraq-, pero desde 
Pedro III se produjo una reorganización espacial de las comunidades hebreas en suelo valenciano, y muchas de ellas ya no volverían a mencionarse en la documentación, como por ejemplo Montesa, concentrándose los judíos en los más importantes centros urbanos. De otras, apenas nos han quedado noticias. Es el caso de Denia, donde para el siglo XIII la única noticia conservada es la concesión real el 21 de noviembre de 1276 de la bailía de la villa a Muçe de Denia. Los judíos de Alcoi y Cocentaina se mencionan únicamente en 1274, a raíz del reparto de tributos entre las juderías de la Corona, contribuyendo con 3.000 y 2.000 sueldos respectivamente. Es una suma importante, si tenemos en cuenta que Valencia pagó 5.000 sueldos, y Sagunto, Onda, Burriana y Segorbe juntas 2.000 sueldos. Lo que llama la atención, sin embargo, es que en todo el siglo apenas vuelve a haber noticias de judíos en estas localidades y las posteriores son también muy fragmentarias para que podamos hacernos una idea clara de la importancia real de estas comunidades. De hecho, en algunas localidades parece que los judíos eran tan pocos que no llegaron a constituirse en aljama, en entidad administrativa propia. Cocentaina, por ejemplo, pertenecía a la contribución de Xàtiva.

\section{Crisis y cambios en el siglo XIV}

La conquista del reino de Murcia por Jaime II y la anexión de parte del mismo tras las sentencias de Torrellas (1304) y Elche (1305) provocó un incremento del número de juderías y de judíos en el reino de Valencia. El rey dio numerosas disposiciones para favorecer la permanencia de los moradores en el territorio y atraer nuevos pobladores. Es ahora, por ejemplo, cuando en Elche, el 27 de agosto de 1296, el rey firma una tregua de siete años con don Juan Manuel, se garantiza a los judíos que tengan heredades de aguas y casas en Elche y su término la posesión de los mismos, pudiendo venderlos, darlos o empeñarlos. $\mathrm{O}$, unos años más tarde, el 10 de febrero de 1307 declaraba francos de impuestos durante e! primer año a todos los que acudieran a residir a Elche ${ }^{2}$. Lo mismo sucedió con los judíos alicantinos, quienes posiblemente apoyaron a Jaime II en su campaña de anexión del reino de Murcia, recibiendo de él diversos privilegios. El 28 de enero de 1298 el rey de Aragón dispuso que los judíos establecidos en Alicante y los que vinieran de fuera en el futuro gozaran de las mismas franquicias que los naturales del país ${ }^{3}$.

2. Hinojosa Montalvo, J., «Los judíos valencianos durante la época de las Vísperas Sicilianas (1282-1336)», XI Congreso de Historia de la Corona de Aragón, Palermo 1984, pp. 195-218.

3. Hinojosa Montalvo, J., «Bosquejo histórico de los judíos en tierras alicantinas durante la baja Edad Media», Els jueus de la Corona d'Aragó durant l'Edat Mitjana, Lleida, 1991. pp.207-220. 
Durante su reinado se pusieron las líneas maestras de la política judía: protección jurídica, pero siempre en situación de inferioridad respecto al cristiano; ratificación de sus privilegios, siempre que no chocaran con los intereses de la Corona o las normas eclesiásticas dictadas en el IV concilio lateranense; fortalecimiento institucional; aumento del control sobre el crédito, exigiendo a los prestamistas judíos actuar con lealtad y no sobrepasar la tasa de interés del veinte por ciento de interés anual. La segregación aumentó en lo referente a la indumentaria y a la alimentación, presionando a los judíos para no compartir carnicerías con los cristianos.

Durante la primera parte del siglo XIV continuó el crecimiento de la población hebrea, ya todos dentro del ampliado reino de Valencia, y siguió obteniendo privilegios de la Corona a cambio de la concesión de subsidios para sus necesidades privadas, pero, sobre todo, para las empresas militares de expansión por el Mediterráneo, como fue la expedición de Cerdeña, cuya cuantía ignoramos, pero que debió ser lo bastante elevada para que entre la comunidad judía se implantaran nuevas formas de fiscalidad, como fue el caso de las sisas sobre los productos que se compraran o vendieran y que en el futuro serían una de las piezas clave en la hacienda de la aljama.

El siglo XIV fue una etapa de crisis generalizada por Occidente, de quiebra de muchos valores y de aparición de otros nuevos. Es ahora cuando se anuncia el futuro hombre del Renacimiento en Italia, pero también fue una realidad el aumento del antijudaísmo en la sociedad cristiana, como acontece en épocas de dificultades, y los judíos eran vistos como los agentes, los causantes de todos los males que afligían a la Cristiandad, lo que se tradujo en violencias contra sus personas y bienes. Un precedente de tales conmociones tuvo lugar en 1320, cuando se produjo la entrada en Aragón de un grupo de «pastorcillos», de individuos que imbuidos de espíritu mesiánico pensaban dirigirse como cruzados contra Granada, aniquilando a cuantos moros y judíos encontraban en su camino. El rey prohibió su entrada en tierras de la Corona y dio órdenes expresas a las autoridades de proteger a las aljamas judías del reino, medida que resultó efectiva.

Si en este caso todo quedó en simple alarma, las guerras de mediados de siglo y las epidemias causaron un profundo quebranto a las comunidades judías, sobre todo las del sur del reino. La peste negra de 1348 y posteriores epidemias debieron reducir la población hebrea en medida imposible de cuantificar, aunque cabe presuponer un elevado índice de mortalidad, igual que entre cristianos y musulmanes.

También resultó muy perjudicial para los judíos la guerra de la Unión, un conflicto de cariz político y social, ya que los judíos saguntinos fueron las víctimas propiciatorias entre realistas y unionistas, al ser asaltada en noviembre de 1348 la villa y la judería por las fuerzas unionistas, «e aquí occiren molts ju- 
heus e juhies, axi grans com pochs, e d'aqui s'en portaren totes les robes, joyes, argent...e altres coses dels dits juheus e de tota la juheria, et... esquinsaren totes les dites cartes debitòries dels dits juheus e juheria $\rangle^{4}$. Desconocemos la cifra de muertos y, como se ve, las cartas de deuda fueron objetivo preferente de los asaltantes. La usura, siempre como telón de fondo del odio entre las dos comunidades. Los judíos, atacados por ser aliados de la Corona, fueron indemnizados con la elevada suma de 64.590 sueldos, que supondría la mitad o tres quintos de lo perdido por los hebreos.

Peores consecuencias para la minoría hebrea tuvo la guerra con Castilla, la de los «dos Pedros» (Pedro I de Castilla y Pedro IV de Aragón), ya que arruinó temporalmente estas aljamas judías, dado que el sur valenciano se convirtió en uno de los principales escenarios bélicos, de los más castigados por los ataques castellanos, tanto por mar como desde el vecino reino de Murcia. La guerra fue una ocasión más para vejar a los judíos, como muestra la disposición del Consell orcelitano de salvaguardar la seguridad de los caminos mediante una fuerza armada, para cuyo mantenimiento los cristianos transeúntes abonarían un dinero por persona, tres los mudéjares y seis los judíos. Sobran los comentarios sobre cual era la consideración de los judíos en la sociedad oriolana.

La guerra, aparte de muertes y cautiverios, debió producir una huida masiva de los judíos en busca de una seguridad que aquí no existía. La Corona dejó de percibir sus tributos y en Alicante en 1366 no quedaba un solo judío («en la dita vila ne en son terme no estan alguns juheus per ocasió de la dita guerra») $)^{5}$. En Orihuela, donde la situación de peligro fue extrema, el municipio tuvo que echar mano de los judíos, para lo cual el 17 de agosto de 1360 propuso que fueran empadronados y divididos por decenas, participando en la vigilancia de la villa, con el argumento de que vivían intramuros, igual que los cristianos. La realidad es que, conquistada Orihuela por Pedro I de Castilla, la judería quedó destruida, y en 1366, cesadas las hostilidades, el rey de Aragón quiso proceder a su reconstrucción, para lo cual el 10 de septiembre, y a instancias de las autoridades locales -conscientes del positivo papel económico que desempeñaban los judíos-, enfranquecía a todos los hebreos que allí acudieran a residir, de todos los derechos vecinales y reales, más la pecha, tributo, cena, etc., durante los próximos cuatro años.

\footnotetext{
4. Puede verse un análisis detallado de este asalto en la obra de DíAz Borrás, A., «Los judíos de Morvedre durante la crisis de 1348-1349», en ARSE. Boletín del Centro Arqueológico Saguntino, nº 38 (2004), pp. 241-312.

5. Hinojosa Montalvo, J., «La Edad Media», en Historia de la ciudad de Alicante. Edad Media, Alicante, Ayuntamiento, 1990, pp. 261-384.
} 
Medidas tan generosas dieron sus frutos con rapidez y de nuevo renació la vida y las actividades en las juderías alicantinas, aunque tuvieron que hacer frente a las continuas peticiones de numerario de los monarcas, lo que hizo que en algún caso, como en Elche la recuperación de la aljama no fuera todo lo rápida que cabía esperar y en 1384 se habla de ellos como asats pobres e poqua població, habiendo emigrado muchos de ellos.

La vuelta a la normalidad se quebró -en muchos casos de forma definitiva. Con la violencia cataclísmica antijudía de julio de 1391. Los tumultos antijudíos estallaron en Castilla en medio de una escalada de precios, el vacío de poder real y arzobispal en la diócesis, que permitió las predicaciones incendiarias del arcediano de Écija, Ferrán Martínez, detonante último de la violencia desatada desde Sevilla, cuya judería fue asaltada. Desde quí los ataques a las comunidades judías se expandieron con rapidez inusitada por Castilla y la Corona de Aragón, donde las juderías de Valencia, Barcelona, Girona o Palma, entre otras muchas, fueron asaltadas y saqueadas, siendo forzada su población a convertirse en masa al cristianismo.

En las comarcas valencianas hubo de todo, desde juderías que desaparecieron, como las de Morella, Alzira, Xàtiva, etc., a las que se salvaron gracias a la protección de las autoridades, como Sagunto u Orihuela. En esta villa, conocidos los sangrientos sucesos de la destrucción de la judería de Valencia ( 9 de julio), los notables de la aljama judía solicitaron la protección de las autoridades cristianas, bajo la amenaza de marcharse de la ciudad. Dicha protección permitió que no se produjeran violencias físicas contra los judíos, lo que no impidió la extinción de la judería, ya que como anota un documento «tro per tot lo XVI dia del mes de juliol aprés següent se tornaren christians». Y otro tanto sucedió en Elche, Castellón, Alcoi, etc., donde desaparecieron las comunidades judías, más que por violencia física por las conversiones forzosas al cristianismo de los hebreos. Un hecho a destacar, sobre todo en el caso de Valencia, donde estaba la principal aljama, fue la ineficacia de las autoridades reales y municipales en la mayoría de los casos para contener el tumulto y castigar a los culpables. Como siempre se echaba la culpa a los forasteros, a los vagabundos, castellanos, galeotes, niños y adolescentes, cuando en realidad participaron miembros de todos los grupos sociales, desde frailes y caballeros a artesanos y marginados. Las implicaciones políticas y sociales eran tantas y tan complejas que no hubo manera de llegar a un acuerdo para resolver tal desacato con verdadera justicia. El rey, cuya autoridad y cuyo patrimonio se habían visto sensiblemente perjudicados, no tuvo más remedio que transigir para mantener una paz ciudadana muy alterada en aquellos tiempos por las luchas de bandos, y al final todo quedó en el castigo simbólico de unas cuantas personas y unas multas en dinero a las villas y ciudades cuyas juderías quedaron destruidas. Tensiones sociales, antijudaísmo, causas religiosas y económicas (la 
usura), todo se unió para hacer de los judíos el chivo expiatorio de los reajustes internos en la propia sociedad cristiana. A partir de 1391 ya nada iba a ser igual y la «solución final» no era más que cuestión de tiempo, como veremos.

\section{Del «problema judio» al «problema converso»}

Ignoramos cuántos judíos murieron víctimas de estos ataques o cuántos se bautizaron, aunque estos últimos serían la mayoría. Con todo, algunas aljamas judías valencianas consiguieron remontar la crisis de 1391. Otras, sin embargo, entraron en una decadencia paulatina y acabaron extinguiéndose, como sucedió con la de Valencia, donde el rastro de los judíos se pierde a partir de los años treinta del siglo $\mathrm{XV}^{6}$. Muchas desaparecieron para siempre y en localidades como Morella, Sant Mateu, Alzira, Gandía, Alicante, etc. dejó de haber judíos de forma regular, sustituidos por los nuevos conversos al cristianismo. En la ciudad de Valencia desde las Cortes de 1403 se limitó la presencia de los judíos, salvo el tiempo necesario para resolver sus asuntos personales, prohibiéndoseles residir en las parroquias de la antigua judería y cualquier contacto personal con los conversos. Los judíos forasteros necesitaban la autorización del baile general del reino para permanecer en Valencia, como hizo en 1475 con Durant Maxuni, de Marsella, y Passero de Aviñón, que vinieron a Valencia a comerciar en las galeazas florentinas, a fin de que puedan residir en la ciudad el tiempo que la embarcación estuviera surta en el Grao de Valencia ${ }^{7}$.

En localidades como Castellón de la Plana, Burriana, Vila-real, Elche, Orihuela, etc. la recuperación demográfica será lenta, y en algún caso, como en Xàtiva, no llegaría hasta mediados del siglo xv. En Castellón de la Plana podemos hablar de refundación de la aljama judía de la villa a partir del privilegio de Martín el Humano del 3 de febrero de 1400 por el que autorizaba a las cinco familias judías que allí residían a elegir adelantados y constituirse en aljama, pudiendo promulgar ordenanzas comunales y aplicar sisas, además de declarar exentos de pecha durante diez años a los hebreos que acudieran a instalarse en la localidad ${ }^{8}$.

En Orihuela el regreso de los judíos a la ciudad fue lento y, aunque los fueros aprobados en Cortes prohibían que se hiciera nueva judería, en 1417 el Consell de la villa intentaba que volviera la población hebrea a fin de combatir los fraudes de los sastres cristianos. Parece que se consiguió, en fecha que ignoramos,

6. Hinojosa Montalvo, J., En el nombre de Yaveh. La judería de Valencia en la Edad Media, Valencia, Ajuntament, 2007.

7. A.R.V. Bailía, 1296, fol. $128 \mathrm{v}$.

8. A.C.A. C. reg. 2193, fol. 134 v-135 v. Hinojosa Montalvo, J., The Jews in the Kingdoom of Valencia. From the Progroms to the Expulsion, (1391-1492), Jerusalem, Hispania Judaica, 1993, pp. 475-476. 
pero fue peor el remedio que la enfermedad, a ojos de los munícipes, ya que el 16 de septiembre de 1430 acordaron requerir al gobernador y al baile general de Orihuela que procediera a su expulsión, a causa de los numerosos fraudes que cometían (imaginamos que en el préstamo y las corredurías). La propuesta no prosperó y en 1447 ya estaba organizada la aljama judía, que pechaba 1.000 sueldos. No sabemos su número y quizá procedieran de las antiguas familias locales, emigradas a Murcia y del cercano valle del Vinalopó, ciudad con la que siempre mantuvieron intensos contactos familiares y comerciales, o a los señoríos del término oriolano, donde gozaban de la protección señorial. Ignoramos lo sucedido con motivo de la expulsión, cuántos salieron y por qué puerto.

El descenso demográfico, fruto de las abundantes conversiones, además de las muertes y emigraciones de 1391, trajo una reorganización en la jerarquía de estas aljamas, pasando a ocupar Morvedre (Sagunto) el papel rector, seguida por la judería de Xàtiva, ambas en enclaves estratégicos desde el punto de vista de las comunicaciones. Sólo en estas dos localidades puede decirse que los judíos tuvieron una importancia demográfica real, que en el caso de Sagunto llegó a un tercio de la población local en el momento de la expulsión. En todo caso, las comunidades hebreas del reino de Valencia eran, salvo las dos excepciones citadas, pequeñas, en algún caso de unas cuantas familias, como las del área alicantina, aunque no tenemos fuentes demográficas específicas para conocer su evolución interna en el siglo xv. Tan sólo podemos afirmar de forma general y a partir de los contratos de embarque en 1492 que los judíos del reino superaban en poco el millar de personas. Una cifra exigua, que está muy lejos de las 100.000 personas de religión mosáica que se calcula que vivían Castilla9.

Durante el siglo XV, el miedo y la sensación de indefensión por los sucesos de 1391 crearon unas condiciones óptimas para las conversiones, insinceras en muchos casos, ya que a pesar de llamarse cristianos de nombre en su corazón se sentían judíos y seguían practicando las ceremonias judías. Se produjo así el tránsito del problema judio al converso, como han dado en llamarlo los autores, generándose un aumento de la intolerancia, sobre todo por parte de las autoridades municipales y un descenso del peso específico del judaísmo en el reino de Valencia, salvo los casos concretos de Sagunto y Xàtiva, donde radicaban las dos juderías más importantes.

\section{La solución final. 1492: Annus horribilis}

La época de los Reyes Católicos (1474-1504) supuso para Castilla el triunfo de la monarquía autoritaria, cuyo programa político iba a tener profundas

9. Ladero Quesada, M. A., «El número de judíos en la España de 1492: los que se fueron», en A. Alcalá (ed.), Judios, sefarditas, conversos, Valladolid, 1995, pp. 170-180. 
consecuencias para las minorías étnico-religiosas, no sólo de esta Corona, sino también en la de Aragón, de la que era monarca privativo Fernando II.

Los reyes, al comienzo de su reinado, siguieron con la tradicional política hacia las minorías, consistente, por un lado, en reafirmar los ordenamientos contrarios a mudéjares y judíos, a la vez que garantizaban su protección a unos y otros. Tolerancia y discriminación, con estos dos principios podríamos resumir dicha política, que, naturalmente afectaba también a los escasos judíos que quedaban en el reino de Valencia. Si en Castilla las Cortes se preocupaban por aplicar leyes discriminatorias y segregacionistas hacia los judíos, las instituciones valencianas permanecían ajenas a tal problemática, que quedaba dentro de los límites municipales. Las leyes forales eran lo suficientemente claras al respecto de tal discriminación que no hacían falta normas adicionales, tan sólo voluntad de una mayor o menor exigencia en su aplicación en la vida cotidiana. Hay que tener presente que los judíos eran una auténtica minoría en el conjunto demográfico del reino y sólo en Sagunto o Xàtiva formaban una población apreciable. En la capital del reino, Valencia, hacía décadas que habían desaparecido y si había algún judío era foráneo y su estancia temporal. Aquí no se vivieron movimientos de exaltación religiosa como en Castilla y, sobre todo, en la Andalucía de finales del siglo xv, donde cristianos, musulmanes y judíos estaban inmersos en ideas mesiánicas y apocalípticas. Tampoco el problema converso tenía la gravedad que en Castilla, donde se habían generado duros enfrentamientos socio-religiosos (Toledo, Andalucía) entre cristianos viejos y cristianos nuevos, que en su radicalización habían arrastrado a los judíos. La asunción de posiciones extremas acabaría por llevar a la victoria de unos y a la desaparición de otros, en este caso de los judíos de la Corona de Aragón y, en concreto, de los del reino de Valencia, víctimas de un radicalismo existente más allá de nuestras fronteras. El resultado final fue la restauración de la vieja unidad política y religiosa de Hispania, gracias al triunfo de los cristianos y la expulsión de los judíos en 1492 y la conversión forzada de los mudéjares a partir de 1502 .

La actuación de los monarcas peninsulares en relación con los judíos se basaba en la provisionalidad de la presencia hebrea, ya que la única posibilidad que tenían de integrarse en la sociedad cristiana era a través del bautismo, puesto que, como señala L. Suárez, la unidad de la fe era la principal seña de identidad para la sociedad cristiana medieva $1^{10}$. Los reyes no manifestaron una actitud antijudía, pero nada hicieron para cortar o frenar el creciente antijudaísmo popular, ni por rebatir las tesis opuestas a los judíos. Se protegía a los judíos porque eran parte del tesoro real y sólo la monarquía podía disponer libremente de ellos. Esto era

10. SuÁrez Fernández, L., Judios españoles en la Edad Media, Madrid, 1980. 
también lo que pensaba la mentalidad de la mayor parte de la sociedad valenciana bajomedieval, tal como se ve en la actuación de las autoridades locales allí donde había juderías.

Durante el reinado de los Reyes Católicos la vida de los judíos valencianos desde una perspectiva global, para todo el reino, puede afirmarse que transcurrió dentro de los cauces de la normalidad cotidiana. Eran pocos, su papel económico apenas trascendía el marco local o comarcal en aquellas localidades donde estaban instalados y no hubo judíos valencianos -ni de la Corona de Aragón- desempeñando papeles importantes en la corte, como sucedía en Castilla, donde los monarcas habían confiado siempre en la lealtad y competencia de sus consejeros judíos y conversos. La decisión de la expulsión se fraguó en la corte castellana, pero sus consecuencias alcanzaron también a los judíos de los Estados de la Corona de Aragón.

La expulsión de los judíos en 1492 es sin duda uno de los temas estrella en la historiografía en torno a esta minoría y una de las decisiones políticas más controvertidas de Fernando e Isabel, calificados por ello como Reyes Católicos. Si buscamos los antecedentes inmediatos de la expulsión, éstos se encuentran en la Corona de Castilla, en cuyas Cortes de Madrigal de 1476, en plena guerra civil entre los Reyes Católicos y Juana la Beltraneja, los monarcas declararon su intención de seguir manteniendo la política regia de protección a los judíos. Pronto, sin embargo, se produjo un cambio radical como consecuencia del viaje de los monarcas a Andalucía en 1477 para su pacificación. Allí se encontraron con un panorama convulso, en particular en Sevilla: floreciente judaísmo hispalense, alto número de conversos que judaízaban, al calor del clima de efervescencia espiritual que florecía entre cristianos, judíos y musulmanes, imbuidos de ideas mesiánicas y apocalípticas, que les hizo adoptar posturas radicales a la espera de la llegada del Mesías o el Anticristo, preludio del fin de los tiempos, que sería vencido por el rey don Fernando, triunfantes los cristianos sobre musulmanes y judíos ${ }^{11}$. El resultado sería el establecimiento de la Inquisición en Sevilla el 1 de noviembre de 1478 por bula del papa Sixto IV. A partir de aquí y de las Cortes de Toledo de 1480 se caminó hacia la solución final, la eliminación del judaísmo de los territorios de los Reyes Católicos, tratando de justificar de forma rápida y lo mejor posible el problema de los conversos judaizantes, ya que muchos estaban convencidos de que mientras hubiera judíos existiría el peligro de contaminación para los conversos, teniendo en cuenta, además, que los judíos, al no ser cristianos, escapaban a la jurisdicción inquisitorial. Este era el razonamiento de los inquisidores que logró calar en el espíritu de los monarcas y se plasmó en la

11. Mackay, A., «Andalucía y la guerra del fin del mundo», en Actas del V Coloquio Internacional de Historia Medieval de Andalucía. Andalucía entre Oriente y Occidente (1236-1492), Córdoba, 1988, pp. 329-342. 
expulsión de los judíos de Andalucía - donde el problema converso era más grave- el 1 de enero de 1483. La guerra de Granada, a la que los judíos contribuyeron con grandes sumas de dinero, paralizó de momento, según algunos autores, la expulsión total de los judíos.

Tras la caída del reino nazarí de Granada, Fernando e Isabel firmaron el 31 de marzo de 1492 el edicto de expulsión de los judíos de las Coronas de Castilla y Aragón, según el cual disponían de tres meses para expatriarse o abjurar del judaísmo y bautizarse. El 1 de agosto no debían quedar ya judíos en sus Estados. Terminaba así un periodo de la historia de los judíos en Castilla y Aragón que se había creído inamovible, eterno, algo que nunca podría suceder.

Parece que los reyes buscaban el máximo de conversiones, algo que no se produjo, aunque todo apunta a que tuvieron cierta entidad, al menos en Castilla, pues abundan las noticias de judíos retornados a sus hogares desde el exilio. No sabemos las posibles conversiones que hubo entre los judíos valencianos ni si hubo presiones para ello, aunque cabe pensar que sí, a tenor de lo sucedido en otros lugares de Castilla o Aragón, pero no hay datos sobre ello. Las actas municipales ni la documentación privada no recogen noticias en este sentido y tan sólo se tiene constancia de la liquidación de bienes por parte de los judíos, cancelación de deudas y préstamos o el pago de los impuestos pendientes, censales, violarios, etc. de particulares y aljamas, con el fin de dejar todos los asuntos económicos y fiscales antes de embarcarse. A los judíos les interesaba llevarse dinero, joyas, letras de cambio, etc., todo aquello que les permitiera rehacer sus vidas en sus nuevos asentamientos.

Hace años tuvimos la suerte de encontrar los protocolos notariales referentes a los contratos de embarque de diversas aljamas aragonesas y las valencianas, lo que nos permitió sacar algunas conclusiones sobre la salida de los judíos del reino de Valencia

El viaje hacia los puntos de partida quedaba garantizado por la potestad real, que velaba por evitar ultrajes y atentados contra sus personas y bienes. Los judíos valencianos salieron hacia sus destinos por vía marítima. También por el puerto de Valencia lo hicieron destacados miembros de la familia castellana de los Abravanel, como don Ishaq, Yosef y Jacob, rumbo a Nápoles, llevándose mercancías valoradas en 460 libras. En el Grao de Sagunto embarcaron los judíos de esta villa y los de Castellón y Xàtiva, además de los de las juderías aragonesas de Teruel, Ariza, Epila, Daroca, Albarracín, Belchite y Huesca. Hay que pensar que los de la gobernación de Orihuela partirían hacia el exilio por el puerto de Cartagena, pero desconocemos su destino exacto.

Los contratos de embarque de los judíos saguntinos y setabenses fueron gestionados ya desde el 9 de mayo por las propias aljamas con mercaderes genoveses actuando como intermediarios mercaderes conversos valencianos, que trataron 
de conseguir unas buenas condiciones para sus antiguos correligionarios ${ }^{12}$. Los conversos valencianos se encargaron también de gestionar las deudas y asuntos pendientes de los desterrados, para luego transferírselos a sus lugares de destino. En los contratos se detallan minuciosamente las condiciones del viaje, pago de fletes, productos que pueden transportar, etc. Los destinos eran el puerto de Pisa, donde estarían ocho días, pudiendo desembarcar quienes quisieran. Desde allí partiría hacia Nápoles, donde descargaría en ocho días las personas y mercancías restantes. Si los genoveses prohibían el atraque en Pisa, en ese caso el destino sería Civitavechia-Nápoles. Otro destino fue el norte de África: Orán, Bugía, Argel o Tenés.

¿La pregunta que todos se hacen es ¿cuántos judíos fueron expulsados? La polémica estaba centrada siempre en la Corona de Castilla y del reino de Valencia nunca se hacía mención. Hoy tenemos cálculos bastante aproximados y podemos decir que en la Corona de Aragón partieron hacia el exilio, siendo entre 4.000 y 6.000 los que salieron del reino de Aragón ${ }^{13}$, unos 3.000 los que lo hicieron de Cataluña ${ }^{14}$. En el reino de Valencia había pocos judíos a fines de la Edad Media. Conocemos su número a través de los contratos de embarque que firmaron antes de partir, pudiendo evaluarse en torno al millar de personas, de ellos 248 de Xàtiva y 700 los de Sagunto, la principal judería del reino. Aún cuando no tenemos constancia del número de judíos que salieron de Castellón, Orihuela y alguno que otro disperso por localidades del reino, los datos conservados apuntan en torno a ese millar o poco más de judíos que embarcaron rumbo al destierro.

Las consecuencias de la expulsión en el reino de Valencia son difíciles de evaluar, aunque podemos afirmar que apenas las hubo desde el punto de vista social y económico, dado el reducido número de judíos que quedaban en el mismo y porque la burguesía y el artesanado conversos de Valencia y otras localidades había suplido a los judíos en el desarrollo socio-económico del reino. Sí fueron desastrosas para la demografía de aquellas localidades donde suponían una aportación importante en el conjunto poblacional, como era el caso de Sagunto y Xàtiva, aunque de esta ciudad no se han conservado noticias. En Sagunto, por ejemplo, se produjo el hundimiento del arriendo de los molinos harineros del rey, aunque el mayor problema estaba en qué hacer con las casas que fueron de los judíos y cómo amortizar el descenso de las arcas reales, al dejarse de cobrar la pecha de los judíos, que era de 2.150 sueldos anuales. La solución pensada el 25

12. Hinojosa Montalvo, J., «Solidaridad judía ante la expulsión: contratos de embarque (Valencia, 1492)», en Saitabi, XXIII, 1983. pp. 105-124.

13. Motis Dolader, M.Á., La expulsión de los judios del reino de Aragón. p. 304-315.

14. Riera i Sans, J., «La Catalunya jueva del segle XIV», en L'Avenç, Barcelona, 1980, 25, p. 55. 
de junio de 1493 fue declarar libres y francas aquellas casas, hasta entonces vacías, y explotarlas, atrayendo nuevos pobladores. La fórmula adoptada fue la de prestar 30 libras por la bailía general a todos los pelaires y tejedores de paños que allí se quisieran asentar, y el 3 de septiembre de 1393, tras pregonarse la oferta en Valencia, ya estaban todas las casas ocupadas. Fue un record absoluto, pues se hizo en tres días, y, lo que era más importante, se consiguió crear una industria textil local, que potenciase el futuro de la villa y amortiguase la expulsión de los hebreos. Estos pelaires y tejedores se organizaron en cofradía según el modelo y los privilegios de los de Valencia, de donde serían oriundos.

En definitiva, fueron las profundas convicciones religosas y políticas de Fernando e Isabel y la necesidad de lograr la cohesión social, las que facilitaron la expulsión de los judíos. Se hizo realidad la unidad religiosa y política fraguada en el principio de $« c u i u s$ regio eius religio» ${ }^{15}$.

\section{LA SOCIEDAD Y LAS ACTIVIDADES DE LOS JUDÍOS}

La población predominante estaba compuesta por pequeños artesanos, comerciantes (sastres, herreros, joyeros, tintoreros, zapateros, humildes tenderos) a ellos se unieron, en las de mayor relieve, grupos importantes de intelectuales (rabinos, especialistas en el estudio de la Torá o ley judía, médicos, etc.) así como pequeños prestamistas, puesto que los grandes financieros o arrendadores de impuestos sólo existían en la judería Valencia.

Así, la sociedad judía se hallaba dividida en dos grupos bien diferenciados social y económicamente: la gran masa de humildes, y el sector oligárquico, que gobernaba e imponía su poder en las aljamas y que estaba mal visto, llegando con el tiempo a ser censurado por sus correligionarios que no aceptaban su estilo de vida y su excesiva influencia averroísta, lo que generó fuertes tensiones sociales en el seno de las comunidades más importantes, sobre todo por el reparto y el pago de las cargas fiscales. Algunos de estos oligarcas judíos se convirtieron, en un momento u otro, en los auténticos amos y señores de las aljamas, como fue el caso del destacado financiero valenciano Jafudà Alatzar, quien, protegido por la Corona, necesitada de sus préstamos, cometió toda clase de abusos-según sus enemigos- convirtiéndose en un dictador de la aljama, a la que impuso sus criterios personales. Su muerte provocó la ruina del clan familiar, inmerso en pleitos sin fin por la herencia ${ }^{16}$.

\footnotetext{
15. Suárez Fernández, L., Judios españoles en la Edad Media, Madrid, 1980; SuÁrez Fernández, L., La expulsión de los judios de España, Madrid, Mapfre, 1991.

16. Riera i Sans, J., «Jafudà Alatzar, jueu de València (segle XIV)», en Revista d'Història Medieval, 4, 1993, pp. $65-100$
} 
El ejemplo de Alatzar ilustra a la perfección cuál era la realidad de la sociedad judía, valenciana o de cualquier otro lugar: una sociedad pluriforme. En ocasiones se ha tratado de presentar a los judíos o conversos como una sociedad armónica, cohesionada frente a cristianos y musulmanes, en la que todos vivían en paz y armonía bajo la dirección espiritual y comunitaria de sus rabinos y dirigentes. Pero la aljama no era un bloque homogéneo ni todos los individuos eran iguales, ni disfrutaban de la misma consideración social, sino que la realidad cotidiana de la documentación nos muestra las rivalidades y las luchas internas que se mantenían en seno, en particular por el control de los cargos de gobierno y por la distribución de los impuestos, de la fiscalidad, en el seno de la misma. En Aragón son bien conocidos los choques entre judíos francos y pecheros, que también encontramos en Valencia, aunque con menor intensidad. Las acusaciones de corrupción y de prevaricación ante el baile general del reino o el monarca, en última instancia, contra individuos concretos, fueron una constante en estos siglos bajomedievales. Las acusaciones de fraude, impiedad -las peleas por los bancos, por el lugar a ocupar, en las sinagogas eran habituales-, la falta de solidaridad, formaban parte de la vida diaria del judío. No en vano, el malsín, el difamador, el acusador, se convirtió en un personaje «típico» de las juderías, duramente perseguido y castigado tanto por la propia comunidad judía como por la Corona.

En definitiva, una sociedad similar a la cristiana en su estructura, en la que los linajes principales fueron el elemento que articulaba una extensa parentela unida por vínculos de sangre, economía, vecindad, etc. Estos linajes se aliaron o lucharon entre sí por conseguir la dirección de la aljama, para lo cual desarrollaron amplias estrategias matrimoniales y políticas, de las cuales conocemos ya algunos casos para el reino de Valencia, como la familia Suxén ${ }^{17}$ o los Legem de Castellón ${ }^{18}$. Podemos afirmar, sin ningún género de duda, que las juderías más importantes estaban enormemente fragmentadas en bandos, lo cual no es una singularidad judía, sino que forma parte del marco social de los siglos finales de la Edad Media, en los que se desarrolló esta sociedad judía. Recordemos que Isaac ben Sheshet Perfet, el gran rabino de Valencia en el momento del asalto a la judería en 1391 había tenido que huir de Zaragoza de estas luchas de bandos, en concreto los ataques de la familia Abnarrabí. Es bien elocuente ver como en medio de la sinagoga Salomón Abnarrabí se atrevió a tirar de las barbas del gran rabino, con

17. Hinojosa Montalvo, J., «From Suxén to Salvador: The Saga of a Valencian Lineage», en Hispania Judaica Bulletin. Articles, reviews, Bibliography and Manuscripts on Sefarad, The Hebrew University of Jerusalem. Institute of Jewish Studies, n² 2, 5759/1999, pp. 17-33.

18. Mira JóDAR, A. J., «Els diners dels jueus. Activitats econòmiques d'una familia hebrea al mon rural Valencià», en Revista d'Història Medieval, 4, (1993), pp. 101-127. 
el que no estaba de acuerdo, lo que provocó la ira de sus seguidores. Es muy difícil precisar estos aspectos desde dentro de las propias aljamas, por falta de fuentes específicas, pero los indicios desde el exterior no dejan dudas al respecto.

Un aspecto todavía mal conocido y por estudiar en la sociedad judía valenciana es el de los esclavos judíos o en poder de los judíos. En principio los cristianos no podían tener cautivos judíos, como así fue, pero hubo excepciones a cargo de los judíos oriundos del reino de Granada y del norte de África, de Berbería, que de cuando en cuando aparecen en la documentación reclamando su libertad. Es el caso, por citar un ejemplo, de la orden dada el 10 de agosto de 1383 por Pedro IV al baile general del reino para que le remita a su corte el proceso incoado contra los judíos de Berbería que fueron apresados y convertidos en cautivos por Ramón de Romaní, doncel, los cuales habían apelado al rey contra dicha cautividad. Es importante señalar que la presencia de esclavos judíos en tierras valencianas se incrementó a comienzos del siglo XVI, en 1509-1510, tras la toma de las plazas de Orán y de Bugía, siendo presentados ante el baile general por sus compradores para que los declarara de buena guerra. Muchos de ellos se bautizaron, por lo general con la esperanza de recuperar la libertad, una vez ya cristianos. Es el caso de Antón de Murcia, hostalero del Grao de Valencia, que el 5 de julio de 1509 presentó al baile general como cautivo a Pedro, un judío de 18 años. Declaró que tenía a su madre y a sus dos tías cautivas en Alicante, donde él había sido bautizado. Fue vendido en 20 libras ${ }^{19}$. Algunos de estos judíos, al igual que los cautivos mudéjares, fueron autorizados por el baile general a recaudar la suma necesaria para su rescate, como se hizo en 1408 con Jacob Bengarbat, judío de Tedeliz, en Berbería.

El rescate de sus correligionarios cautivos fue para los judíos, igual que para cristianos y musulmanes, una obra de caridad que formaba parte de su vida cotidiana, y sabemos que el 3 de mayo de 1386 Pedro IV, a petición de los mensajeros de la aljama de Valencia, concedió a la misma que, mediante el pago de 30 florines por individuo, pudieran redimir a los judíos que se llevaran a Valencia para ser vendidos como esclavos y que hubieran sido cautivados por piratas cristianos o musulmanes.

La guerra, la piratería o la mala fortuna eran causas de esta cautividad. Es lo que le sucedió al judío Mordoxeu Abencrespo, judío que viajaba en una carabela portuguesa que desde Barcelona regresaba a Portugal, pero el mal tiempo la hizo naufragar en la playa de Denia, donde fue apresado con ciertas telas. Estuvo 53 días preso en la cárcel de Valencia y luego vendido en subasta, siendo adquirido

19. A.R.V. Bailía, 196, fol. 328 v-329 r. Lo cita CoRTÉs Alonso, V., La esclavitud en Valencia durante el reinado de los Reyes Católicos, Valencia, Ayuntamiento, 1964. Regesta nº 1.015. 
el 26 de junio de 1465 por la suma de 1.320 sueldos por el Mercader de Valencia Joan Pascual ${ }^{20}$.

Los judíos más acomodados poseían, igual que los cristianos, cautivos musulmanes, aunque es imposible saber la difusión de la esclavitud entre la sociedad judía, dado que sólo nos han llegado noticias aisladas. Vemos como el 19 de diciembre de 1334 los jurados de Valencia escribieron al noble don Juan Manuel, notificándole la situación de dos moros de Benaguasil, vasallos de don Lope de Luna, apresados por el lugarteniente de procurador del reino de Valencia y vendidos a Samuel Abendano, almojarife de don Juan Manuel, y a Mossé Almateri, de Xàtiva. Como dichos moros eran francos tuvieron que ser puestos en libertad ${ }^{21}$.

Frente a lo que sucedía en Castilla y en menor medida en Aragón, en el reino de Valencia los judíos vivieron agrupados en barrios específicos, las juderías, allí donde eran muchos, o bien en calles específicas, buscando la protección y la defensa de su identidad. En localidades como Cocentaina, Alcoi, Elda, Aspe, etc., con pocos judíos, nunca se menciona la existencia de un barrio judío.

Conocemos bien el caso de Valencia, ciudad en la que el perímetro de la judería fue expresamente delimitado por Jaime I el 20 de octubre de 1244, cuando dispuso que estaría delimitado por «el adarve Abingeme, hasta el baño de Almelig, y desde aquí hasta la puerta de la Xerea, y de esta puerta hasta el horno de Albimulliz y hasta el adarve de Abrahim Alvalencíi ${ }^{22}$. Los judíos que poblaran la judería valenciana se regirían por los fueros y costumbres de la aljama de Barcelona, que fue -junto con la de Zaragoza- la que el monarca aragonés tomo como modelo para la nueva instalación de Valencia ${ }^{23}$.

Razones de seguridad hicieron que las juderías estuvieran emplazadas cerca de los centros de decisión política y religiosa, junto a la catedral, como fue el caso de la ciudad de Valencia, o bien al amparo de las fortalezas, como en el caso de Sagunto, Xàtiva u Orihuela. Los judíos, que eran considerados como

20. A.R.V. Maestre racional, 75, fol. $172 \mathrm{v}$.

21. A.M.V. Lletres misives, g3-1, fol. 52 r-v. 19-12-1334, Valencia.

22. Codorn, T. XI, p. 290. Llibre del Repartiment, «Iudei in Valencia habitants et habitaturi totum illum barium sicut incipit de Ladariis Abingeme usque ad balneum d'En Almelig et ab isto loco usque ad portam Exarea, et ab porta usque ad furnum de Albimulliz et usque ad adarp de Abrahim alvalenci; et volumus quod habitent et populentur secundum forum et consuetudinem aliame Barchinone». Danvila y Collado, F., «El robo de la judería de Valencia en 1391», Boletín de la Real Academia de la Historia, T. VIII, (1886), p. 380; Rodrigo Pertegás, J., «La judería de Valencia», apéndice a la obra de SAnchis Sivera, J., La Iglesia parroquial de Santo Tomás, Valencia, 1913, pp. 245-269, en concreto p. 246, nota 1. Señalemos que LACAVE, J. L., Juderías y sinagogas españolas, Madrid, 1992, p. 62 da la fecha errónea de 1245 como la de la fundación del barrio.

23. Hinojosa Montalvo, J., «El reino de Valencia: juderías y sinagogas», Juderías y sinagogas de la Sefarad medieval. XI Curso de Cultura Hispanojudía y Sefardí de la Universidad de Castilla-La Mancha (2001), Cuenca, Universidad de Castilla-La Mancha, 2003, pp. 73-144. 
propiedad del monarca (nostre tresor), preferían vivir juntos por múltiples razones, desde las familiares a las profesionales, pero sobre todo, como decimos, por seguridad, pues el antijudaísmo creciente en la sociedad cristiana a partir del siglo XIII hacía necesario la adopción de medidas protectoras por parte de las autoridades, siendo su manifestación externa más visible la cerca con la que se rodeaban las más importantes juderías. Para los judíos era también una manera de garantizar su aislamiento y preservar sus costumbres. La comunicación con la ciudad cristiana se hacía a través de portales abiertos en el muro, por lo general en las zonas de contacto comercial entre ambas comunidades. Estos muros fueron surgiendo con el paso del tiempo, conforme aumentaba el aintijudaísmo en la sociedad cristiana. Es lo que sucedió en Sagunto, donde el 5 de mayo de 1321, a petición de la aljama, Jaime II dio licencia a los judíos de la villa a erigir un muro que los separase por completo del resto de la población cristiana. La desaparición de judíos de muchas juderías en 1391 tras su conversión hizo que estos portales dejaran de tener razón de ser y las puertas se vendieron a particulares, como sucedió en Orihuela ${ }^{24}$. La judería de Sagunto, la medieval Morvedre, es la mejor conservada de la comunidad y a través de su portal el paseante puede acceder a las estrechas calles y sus placitas que la conformaban, con las viviendas de planta rectangular, entre las que se ha conservado la que servía de sinagoga, aunque no todos los autores proponen la misma identificación ${ }^{25}$.

Recordemos también que en las juderías no moraron sólo judíos sino que también lo hicieron cristianos, abundando los testimonios de ello en la compraventa de viviendas y, sobre todo, en las reiteradas prohibiciones de las autoridades, que buscaban evitar que los cristianos pudieran contaminarse de la doctrina hebrea. También hay que señalar que las juderías no permanecieron fosilizadas en el espacio urbano, sino que estuvieron en movimiento a lo largo de los siglos, sobre todo allí donde creció la población hebrea y fue necesario ampliar el espacio residencial de esta comunidad, como fue el caso de Valencia, lo que generó un tremendo problema social a partir de 1370 y fue una de las causas que enconaron los ánimos contra los judíos. Otras veces se produjeron traslados espaciales de estas juderías, sobre todo a partir de 1391 en aquellas que habían dejado de cum-

24. Este año el jurado clavario vendió a Pere Guixet unas puertas del portal de la judería por 26 sueldos y7 dineros, y otras dos puertas del citado barrio a Joan Cascant por 16 sueldos y medio.

25. Además de mi artículo ya citado, pueden verse: CIVERA I GoMEZ, M, «La jueria de Morvedre», ARSE. Boletín del Centro Arqueológico Saguntino, 37, Sagunto, 2003, pp. 65-92; Hinojosa Montalvo, J., «Sinagogas valencianas», Sefarad, XXXVIII, Madrid, 1978, pp. 293-307; LACAVE, J. L., «De nuevo sobre la sinagoga de Sagunto», Sefarad, L, pp. 21-213; Muñoz Antonino, F., «La sinagoga en la aljama judía de Murviedro», Arse n⿳38, Sagunto 2004, pp. 313-322.

Muñoz Antonino, F., «La sinagoga de Morvedre. Una sinagoga para la polémica», De Murbiter a Morvedre, Valencia, Bancaja, 2006, pp. 249-259. 
plir dicha función por conversión de sus moradores al cristianismo. Y cuando se volvió a recomponer la judería, a veces lo hizo en espacios urbanos diferentes al originario, como sucedió en Castellón o en la misma Valencia.

La distribución de estas juderías en el territorio valenciano data de los años posteriores a la conquista, aunque en algún caso, como Valencia se rastreen antecedentes de época almohade. Las juderías más importantes desde el punto de vista demográfico y económico coinciden con los núcleos urbanos más desarrollados, ya desde época andalusí, desde Morella a Orihuela, pasando por San Mateo, Castellón, Onda, Vila-real, Burriana, Segorbe, Llíria, Sagunto, Xàtiva, Alzira, Gandía, Denia, Alcoi, Cocentaina, Alicante, Elche, Elda, etc. siempre en las vías de comunicación mas importantes y transitadas, por donde circulaban los hombres y las mercancías, donde había posibilidad de hacer negocio. También había un predominio de las instaladas en localidades de realengo sobre las de señorío. En algunos casos encontramos judíos en núcleos pequeños, como Peñíscola, Montesa, Beneixama, Corbera, de los que sólo queda alguna noticia dispersa de la segunda mitad del siglo XIII y comienzos del XIV, por lo que cabe considerar que se trataba de asentamientos temporales, aprovechando determinadas coyunturas políticas o económicas, y luego estos individuos se trasladaban a otros lugares, ya que, no lo olvidemos, la movilidad de la población hebrea era alta. En cualquier caso a comienzos del Trescientos la red de juderías valenciana estaba ya plenamente configurada.

Desde el punto de vista institucional se agrupaban, igual que los mudéjares, en aljamas, organismo encargado de regir la vida interna de la judería: se ocupaba de dar normas internas, cobrar impuestos, regular los precios del mercado, crear centros de primera enseñanza y asistir a los pobres, etc. En el reino de Valencia, a su frente, se hallaban los adelantats (muccademin), asistidos por consellers, imitando el modelo del municipio cristiano. El dayyan o juez, asesorado por el rabinos, dictaba sentencia en las querellas entre judíos, en función de sus leyes (talmúdicas) y en tribunales propios. Existía también un sayón o policía y el matarife.

Los rabinos, a pesar de no formar parte del grupo dirigente, podían, cuando lo creían oportuno para mantener la disciplina religiosa y la moralidad, tomar todas aquellas medidas, por drásticas que fueran, que creyesen convenientes y la aljama se encargaba de dictar el herem o anatema contra el judío inmoral, sobre todo el acusado de malsinar o difamar a sus correligionarios o a la aljama. El castigo era su aislamiento o la expulsión de la comunidad.

\section{Cultura material y vida cotidiana}

Está por estudiar con detalle el tema de la alimentación judía en el reino de Valencia, aunque ya disponemos de visiones generales, en las que se puede apre- 
ciar la similitud de comportamientos de nuestros judíos con los de otros Estados peninsulares. La carne y el vino son los dos elementos que más distinguen a judíos y cristianos, en virtud de las peculiares normas alimenticias de cada grupo, en cuyo detalle no vamos a entrar. Sí que me interesa destacar que estas peculiaridades, que dan coherencia al grupo judío, son las que generan tensiones con los cristianos, en particular la carne. Con el vino no hay problemas, ya que, o bien lo elaboraban en sus bodegas con el vino propio, o bien compraban la cosecha a cristianos y luego eran los judíos los encargados de producir un vino kasher.

La carne era un alimento básico en la dieta cotidiana de los judíos, en particular la de carnero, cabra, cabrito, cordero, y uno de los objetivos prioritarios de toda comunidad era disponer de su propio matarife, ya que de lo contrario estaban obligados a adquirir carne sacrificada por cristianos, con los consiguientes problemas de impureza que ello acarreaba. Las comunidades trataban de ser autosuficientes, contando para ello con sus propios ganados que pastaban por el término. La concesión de una carnicería era una regalía, siendo preceptivo el permiso del monarca. Valencia, por ejemplo, tuvo su propia carnicería judía por concesión de Jaime I el 15 de julio de 1265, fecha en la que autorizó a la aljama a erigir dicho establecimiento donde quisieran y vender carne sin trabas. A cambio le entregaron la suma de 8.000 sueldos para la guerra contra los mudéjares sublevados ${ }^{26}$.

Pero no siempre se podía disponer de carnicería y matarife propio, y ello lo aprovechaban las autoridades eclesiásticas o locales para presionar a los judíos a la conversión o a la emigración, bajo la excusa de la pureza. Hay muchos ejemplos desde fecha temprana por todo el reino, desde Elche a Castellón. Recojo aquí lo sucedido en Burriana en 1335, cuya aljama se quejo al baile general del reino -último defensor de los judíos- porque el párroco de la iglesia local, por orden del obispo de Tortosa, prohibió a los carniceros locales que cortaran carne en la carnicería de la villa a los judíos. Los judíos explicaron al funcionario real que el rabino degollaba una o dos reses cuando era necesario, pero que si se les prohibía el suministro de carne se marcharían de la villa. Era la típica amenaza de las minorías ante la agresión cristiana: la emigración, con lo que suponía de pérdida de ingresos para las arcas reales, por lo que el baile ordenó que se les siguiera permitiendo degollar reses a los carniceros locales para los hebreos ${ }^{27}$. En Elche los judíos tenían un privilegio por el que los carniceros cristianos les debían facilitar cada día de la semana dos animales lanares casseres.

26. A.R.V. Real, 659, fol. 43 v-44 r. 15-7-265, Tamarite.

27. A.R.V. Bailía, 1142 bis, fol. 4 r-v. 
La carne, el pan, el vino y demás alimentos eran una importante fuente de ingresos para las aljamas, sobre todo desde que a partir de la segunda década del siglo XIV las aljamas fueron consiguiendo el permiso de la Corona para imponer sisas sobre las transacciones de dichos productos. Este impuesto se convirtió en la principal fuente de ingresos fiscales externa de las aljamas, de ahí que los reyes reiteraran en continuos privilegios la prórroga de las mismas. La sisa de la carne se arrendaba anualmente en algunas aljamas, las más pobladas, como Valencia, surgiendo en ocasiones pleitos entre los arrendadores y los carniceros, a los que acusaban los primeros de no tener carne en abundancia como estaban obligados, lo que provocaba el descenso de los ingresos de la sisa. Un pleito de este tipo, por ejemplo, se produjo en la judería de Valencia entre los arrendadores de la sisa y los carniceros Isaac Germezano y Mosse Abella en 1373, siendo obligados estos últimos por la reina Leonor, señora de la aljama, a tener carne en abundancia ${ }^{28}$.

Otra faceta de la vida cotidiana y la cultura material que cada día ofrece nuevas perspectivas es el estudio de la muerte entre los judíos, en concreto de sus cementerios. Después de 1391 y a raíz del bautismo de muchos judíos, algunos de estos fosares quedaron desafectados, convirtiéndose en espacios marginales y almacén de materiales, para el vecindario, aunque los conversos procuraron el traslado de los restos de sus antepasados a un nuevo lugar sacro, como sucedió en Valencia, donde la cofradía de Sant Cristòfol y su cementerio siguieron aglutinando a la comunidad conversa. En Orihuela, por ejemplo, el fosar de los judíos pasó a ser el huerto de J. Rocafull y luego de Marco Antonio Pascual, entre su casa y el río.

Los dos cementerios conocidos y estudiados en la Comunidad Valenciana son el de Valencia y el de Sagunto. En el caso de Valencia se conocían bastantes noticias sobre su ubicación, pero no ha sido hasta fecha reciente en que el derribo de modernos edificios ha permitido su estudio. El cementerio ocuparía una superficie de algo más de dos hectáreas en el área sudoriental de la ciudad, habiéndose descubierto 60 ó 70 tumbas, como mínimo, perfectamente alineadas y en excelente estado de conservación, puesto que desde los siglos XIV y XV no sufrieron alteraciones. Sabemos que en 1363 durante la guerra con Castilla, las autoridades municipales autorizaron utilizar muchas de las piedras del cementerio para construir una presa sobre el Turia y poder abastecer de agua a un molino intramuros. En 1400 otras muchas fueron compradas por el sotsobrer, cuando el cementerio ya estaba en desuso. Las tumbas estaban perfectamente alineadas, una al lado de la otra en calles paralelas; que no habían sido reutilizadas, como

28. A.C.A. C. reg. 1581, fol. 118 v-119 r. 20-5-1373, Barcelona. 
era habitual en los camposantos cristianos o musulmanes para aprovechar el espacio; no había tumbas monumentales, ya que la mayoría eran simples fosas excavadas en el terreno natural, en las que se depositaba el cuerpo amortajado, extendido, descansando sobre la espalda y resguardado por cubiertas poco cuidadas de madera; salvo alguna hecha con piedras, o argamasa, lo normal era la utilización del ladrillo, pudiendo percibirse restos de la madera o clavos de los ataúdes. Predominaba, por tanto, la sencillez en los enterramientos y también en los ajuares, ya que no ha llega ningún resto de ellos, salvo un par de anillos y algún paño que envolvía la cabeza, forma similar a los hallados en el cementerio judío de Barcelona, en Montjuich. A simple vista podía apreciarse que algunas de las personas allí enterradas habían muerto de forma violenta, sufrían diversas enfermedades, como raquitismo o parálisis infantil, o habían sido operadas en la cabeza, siendo frecuentes los matrimonios endogámicos entre la comunidad ${ }^{29}$.

El caso de Sagunto es el de más reciente estudio (1992-2006), de cuyo fosar se han recuperado 14 nuevos enterramientos, que se añaden a los recobrados en 1992, y en él se han puesto de manifiesto dos fases de enterramiento, según M. Calvo, director de las prospecciones. La fase primera, y más antigua, corresponde a un momento de uso del cementerio en torno al siglo XIV. Las tumbas en esta fase están excavadas en un estrato romano del siglo II a E.C. En la segunda fase, fechada en los siglos XIV-XV, se detectó un gran aporte de tierras para subir el nivel funerario inicial y de esta manera poder seguir inhumando en este sector.

Las sepulturas, de morfología trapezoidal, se construyeron con piedras irregulares de caliza y para las cubiertas se utilizaron losas calizas de mayor tamaño. En el relleno de las tumbas se recuperaron clavos pertenecientes a las parihuelas que sirvieron también para transportar los cadáveres y aprovechadas en última estancia para cubrirlos una vez depositados en el interior de las sepulturas. Las inhumaciones son individuales al igual que en los cementerios musulmanes. La postura que ofrecían los esqueletos es decúbito supino con las extremidades superiores e inferiores extendidas con los pies juntos. La orientación al igual que ocurre en el cementerio judío de Valencia y Deza (Soria) es N-S con la cabeza mirando al sur. Los trabajos arqueológicos recobraron restos de tejido perteneciente a un tocado femenino de la cabeza con dos aderezos de plata. También se recuperaron en los esqueletos infantiles femeninos dos pulseras de pasta vítrea de color azul, un par de pendientes de oro, un amuleto de plata y coral blanco, unos pendientes de plata, un collar con cuentas de pasta vítrea y azabache, y agujas de mortaja. Este conjunto de piezas es, sin duda, la más valiosa aportación a

29. Calvo, M., y Lerma, J. V., «El «Fossar dels Juheus», en Saitabi, 46, (1996), pp. 161-277; Hinojosa MonTALVO, J., «Cementerios y minorías religiosas en el Reino de Valencia durante la Edad Media», en Studium. Revista de Humanidades, Homenaje al profesor Antonio Gargallo Moya. 3, Teruel, 1997, pp. 171-185 
la cultura material de los judíos valencianos, de la que apenas quedan restos. En el Museo arqueológico de Sagunto se conservan cuatro lápidas funerarias procedentes del cementerio judío, mientras que otras se utilizaron como material de construcción después de la expulsión de la comunidad judía saguntina en 1492, como se puede advertir en la torre señorial de la vecina población de Benavites. El último hallazgo (2006), en el otro margen del río Palancia ha permitido recuperar la mitad de una nueva lápida que se encontraba en la estructura de un molino ${ }^{30}$.

\section{Las actividades de los judios}

Las actividades de los judíos eran de carácter urbano, acorde con el marco en el que residían y con los hábitos laborales del pueblo hebreo. El panorama es similar a lo que encontramos por estas fechas en otras juderías de la Corona de Aragón y así no encontramos ni una sola noticia hay que nos hable de judíos agricultores o ganaderos, aunque sí que tenían propiedades agrarias, principalmente viñedos, que les proporcionaba el vino que necesitaban para su consumo, que era elaborado de acuerdo con las normas alimenticias propias del pueblo judío. Otras propiedades eran de cereales o de árboles, cultivadas por terceros. En cualquier caso es muy difícil establecer conclusiones sobre el nivel de riqueza en propiedades rústicas de los judíos, dado que no hay relaciones del catastro en estas fechas, con la excepción de Castellón de la Plana, donde se conservan para algunos años los llamados Libres de values de la peyta que permitieron a J. R. Magdalena analizar la propiedad de los judíos en esta localidad ${ }^{31}$. Un análisis más pormenorizado lo representa el trabajo más reciente y más elaborado de $\mathrm{A}$. J. Mira Jódar sobre la familia Legem, la más importante de la judería de Castellón en el siglo $\mathrm{XV}^{32}$, en el que, además de casas y obradores en la judería, podemos ver como el grueso de estas propiedades está constituido por viñedos, tierra de labor, algarrobos y algún frutal. Un panorama similar al de otras juderías importantes del reino, como Valencia o Xàtiva. Las propiedades eran, además de pequeñas explotaciones agrícolas, muy fragmentadas, cuya media no pasaba de las 4 hectáreas, en tanto que las propiedad campesina media en Castellón era de

30. Calvo, M., «El mundo funerario en las tres culturas», en De Murbiter a Morvedre, Valencia, Bancaza, 2006, pp. 263-270; Calvo, M., y Lerma, J. V., «Estudio de los objetos de adorno recuperados en algunos enterramientos del cementerio judío», en De Murbiter a Morvedre, Valencia, Bancaja, 2006, pp. 272-275.

31. Magdalena Nom De Deu, J. R., «Estructura socio-económica de las aljamas castellonenses a finales del siglo XV», en Sefarad, XXXII, (1972), pp. 341-370; Magdalena Nom De Deu, J. R., «Población, propiedades e impuestos de los judíos de Castellón durante la Baja Edad Media», en Sefarad, XXXIV, 1974, pp. 273-288.

32. Mira JóDAR, A. J., «Els diners dels jueus. Activitats econòmiques d'una familia hebrea al mon rural Valencià», en Revista d'Història Medieval, 4, (1993), pp. 101-127. 
4’3 hectáreas. Estas propiedades agrícolas estaban divididas en parcelas alejadas entre sí.

Personalmente analicé no hace mucho los patrimonios y el nivel de riqueza de estos judíos valencianos, partiendo de la constitución de aquéllos a partir de las donaciones de Jaime I a los judíos que venían al reino tras la conquista del monarca aragonés. Llamaba la atención sobre la formación de destacados conjuntos patrimoniales por parte de una serie de judíos situados en el entorno del rey, sobre todo aragoneses, que recibieron en el territorio periurbano de las principales ciudades almunias, alquerías, huertos, etc. que debieron pertenecer a destacados personajes de la etapa musulmana, situados en las mejores tierras y que constituyeron una importante fuente de ingresos para unos propietarios a menudo absentistas. Pero, como todos los autores han señalado, nos encontramos en los reinados de Jaime I y primera parte de Pedro III, considerada la época dorada del judaísmo en la Corona de Aragón, afirmación que se hace extensiva a la propiedad judía, gracias a estas donaciones ${ }^{33}$.

Mención especial merecen las confiscaciones reales en las que se vieron envueltos algunos de los citados funcionarios, como consecuencia de su mala gestión. Como ejemplo citemos el caso de Mossé Alcostantiní, baile de Valencia y otras localidades, que fue procesado por deudas con el rey por razón de su cargo, siendo encarcelado en 1282 y a punto estuvo a punto de perder la vida, acabando con la confiscación de sus bienes y una multa de 50.000 sueldos, lo que da una idea de su cuantiosa fortuna. Entre esos bienes se citan casas en Valencia, 50 maravedíes alfonsíes de oro censales en el término de Sagunto, una almunia junto al río Gállego, propiedades diversas en Calatayud, etc. Poder y mala gestión de estos personajes judíos, junto con una mejor preparación de los cristianos, son elementos que ayudan a entender la animadversión que generaron y la prohibición de ejercer cargos de poder sobre los cristianos a partir de 1283.

Durante el siglo XIv la propiedad judía, al igual que la de los cristianos, siguió los habituales procesos de compras, ventas, particiones, acumulación y disgregación de las mismas, sin que se produjeran graves trastornos en la misma, salvo en momentos puntuales y excepcionales, como fue el asalto por las tropas unionistas de Valencia de la judería de Sagunto o la violencia cataclísmica de 1391, en la que muchos judíos perdieron sus bienes, sobre todo muebles. La propiedad inmueble la formaban viviendas, obradores y corrales, básicamente, a la que se podría añadir algún establecimiento «industrial», como hornos o tintorería, pero la falta de datos impide precisar más.

33. Hinojosa Montalvo, J., «Propiedad y nivel de riqueza de los judíos valencianos», en Os reinos ibéricos na Idade Média, Porto, Livraria Civilizaçao Editora, 2003, vol. 2, pp. 677-686. 
Igualmente y por la citada razón todas las aljamas de cierta importancia poseían ganados propios para su consumo, de algunas decenas o un par de centenares de cabezas, que luego el matarife o shoet sacrificaba según un minucioso ritual. En Elche, por ejemplo, en 1382 las autoridades locales pretendieron que la señoría de la villa no obligara a los judíos a pagar montazgo u otros pechos por ellos, de forma similar a lo que sucedía en la vecina Orihuela ${ }^{34}$.

La actividad comercial era particularmente intensa entre los judíos, establecidos en las localidades más importantes de los ejes viarios, lo que propiciaba tales intercambios, bien en las propias tiendas de los hebreos o en las comarcas vecinas. No sólo se trabajaba para el consumo interno de a judería, sino, sobre todo, cara al exterior, a la venta a los cristianos y mudéjares del entorno. Esta comercialización se llevaba a cabo en el propio obrador, en el mercado y la feria, o bien desplazándose los judíos por la propia comarca o las vecinas, como hacían los de Sagunto por las del Camp de Morvedre y la Plana Baixa. Las relaciones comerciales entre judíos oriolanos y murcianos, entre los que existirían vínculos familiares, eran cotidianas, como las de todos los instalados en el corredor del Vinalopó.

No debemos olvidar tampoco el comercio exterior protagonizado por judíos, bien del reino o forasteros. Es bien conocido el papel que la ciudad de Valencia tuvo como centro destacado de la economía mercantil bajomedieval en el Mediterráneo occidental, cuyo cenit se alcanzó en la segunda mitad del siglo $\mathrm{XV}^{35}$. Pero desde el siglo XIV los judíos de la capital mantenían intensos vínculos comerciales con los vecinos reinos de Aragón, Castilla, así como con Baleares y el norte de África, en estos casos propiciadas por los lazos familiares. Valencia, plaza mercantil de primer orden, era puerto de descarga y almacenamiento de toda clase de mercancías, desde las especias a los esclavos y metales, además de disponer de una importante base agraria y manufacturera. Ello la hacía un centro redistribuidor de productos foráneos para buena parte de la Península Ibérica y aquí acudían en gran cantidad, al menos desde el último cuarto del siglo XIV, judíos portugueses, castellanos, aragoneses, norteafricanos, etc., beneficiándose de este tráfico localidades como Xàtiva y Sagunto, con dinámicas juderías ${ }^{36}$. Los

34. A.M.E. Manual de Consells, 1, 25-3-1382, Elche. Hinojosa Montalvo, J., «Los judíos en Elche durante la Baja Edad Media», en Homenaje a D. Juan Torres Fontes, Murcia, Academia Alfonso X el Sabio, 1987, pp. 791-800.

35. Hinojosa Montalvo, J., «Valencia, centro mercantil mediterráneo. Siglos XIII al XV», en Fiere e mercati nella integrazione delle economie europee. Sec. XIII-XVIII. XXXII Settimana di Studi, Istituto Internazionale di Storia Economica F. Datini, Prato, (Prato, mayo de 2000), Firenze, Le Monnier, 2001, pp. 597-607.

36. Hinojosa Montalvo, J., «Judíos portugueses en Valencia a fines de la Edad Media», en Revista de Cièncias Históricas, $\mathrm{n}^{\circ}$ X, Universidade Portucalense, 1995, pp.221-234; Hinojosa Montalvo, J., «Las actividades mercantiles de los judíos saguntinos. De Valencia a Granada y Berbería», en ARSE, $\mathrm{n}^{\circ} 35$, Sagunto 2001 (publicado en 2002), pp. 101-132. 
judíos, moviéndose de aquí para allá, por todo el Mediterráneo, contribuyeron a dinamizar los intercambios y a relacionar ámbitos mercantiles regionales. Lo testimonia la reclamación presentada por el recolector de las generalidades en Orihuela y el embargo de bienes llevado a cabo por los jurados de la villa en octubre de 1377 contra el judío Mahaluf Jaqim, de Mallorca, quien había fletado un pambil para ir a Cartagena con pastel, tártaro, alumbre, gala y roja. Durante el viaje se detuvo en el puerto del Cap de l'Aljub, en término de Elche, con el fin de entregar algunos cambios a mercaderes de la zona, siendo retenido y embargado por el citado colector. Al margen del resultado judicial lo que interesa destacar es el papel del judío como nexo de unión en asuntos monetarios-cambios-entre Mallorca y el reino de Valencia.

También el nombramiento de procuradores por parte de los judíos, cristianos o conversos, también es otra muestra de tales actividades. En este campo de los intercambios también hubo judíos corredores de cuello (de coll) y de oreja (d'orella), actividad en la que destacaron por su habilidad, lo que les generó la enemistad de sus colegas cristianos, que veían en ellos unos peligrosos competidores, por lo que todo su esfuerzo lo dedicaron a que las autoridades municipales les prohibieran ejercer dicho oficio, como sucedió en el Castellón de 1488.

Pero si alguna actividad ha permanecido ligada a la imagen del judío hasta hacerlos casi inseparables es la del préstamo de dinero con interés, la de prestamista o usurero, que tantos quebraderos de cabeza produjo a las relaciones entre cristianos y judíos. La Iglesia prohibía esta actividad a los cristianos, por lo que fueron los judíos quienes satisficieron la necesidad de capital que aquéllos tenían, siendo la autoridad civil la que reguló las condiciones del préstamo, cuyo interés legal era del 20\%. Para darnos una idea de lo que en la realidad y el imaginario del cristiano de la época representaba esta práctica crediticia baste recordar que la mayor parte del articulado de los Furs referente a judíos está relacionado con estas actividades del manejo del dinero, igual que sucedía en el resto de la Península. Y lo mismo sucedía en las reuniones de Cortes y numerosos privilegios reales, tratando de evitar los fraudes, abusos o lograr una prórroga en las deudas, si bien aunque en tierras valencianas el problema nunca alcanzó la gravedad y las tensiones que se aprecian en otros lugares, como Castilla.

El préstamo era la actividad más generalizada entre los judíos -menos en las mujeres, destacando las viudas-, que se dedicaban a ella en exclusiva o como un complemento a sus actividades ordinarias para incrementar sus ingresos. Los judíos de cada aljama proyectaban su área de influencia sobre la propia localidad y su entorno comarcal, estando integrada la clientela preferentemente de agricultores y artesanos de las localidades donde vivían los prestamistas, sin que faltaran miembros de otros estamentos, como la nobleza o el clero. Este préstamo era de una decenas de sueldos, por lo general, pudiendo llegar a algunos centenares, 
permitiendo satisfacer necesidades urgentes e inmediatas de dinero ante una crisis o un gasto imprevisto, siendo un elemento dinamizador que contribuyó a la viabilidad y mantenimiento de la empresa familiar campesina y artesana ${ }^{37}$.

Como sucedía en el resto de las juderías del reino y peninsulares la mayoría de los judíos eran artesanos, dedicados al trabajo del cuero (calzado) y del textil, sobre todo sastres, así como a la orfebrería (plateros), actividades en las que gozaban de justa fama, gracias a su laboriosidad y a la calidad del producto. Por ejemplo, Yento Aseo, orfebre de Elche, estuvo trabajando en 1391 tres meses para el Consell de Alicante, haciendo una serie de encargos y, lo más sorprendente era que se le instaba a buscar «agua encantada». Nos encontramos, pues, ante un judío alquimista, o eso querían creer las autoridades alicantinas. No faltaron los herreros, como el caso de Yahuda, al que el concejo de Callosa animó a instalar una herrería en la villa por un año, pagándole una barchilla de trigo por cada par de bestias herradas. Yahuda huyó a Murcia en julio de 1391 cuando se enteró de la violencia antijudía en Valencia. El obrador era el marco familiar de trabajo y también, a menudo, el de venta del producto, igual que en el mundo cristiano y mudéjar. Digamos también que en el reino de Valencia no fueron frecuentes las asociaciones profesionales de artesanos judíos, lo que conocemos como gremios, en contraste con lo que sucedió en Aragón, donde sí las hubo. Al menos no se han conservado las noticias. Todas las corporaciones de oficios cristianas excluían de las mismas a los miembros de las otras religiones, musulmanes y judíos.

Los artesanos judíos sin duda eran considerados necesarios para el desarrollo de la economía local allí donde estaban instalados, pero siempre fueron vistos con hostilidad, como rivales, por los cristianos. De ahí que toda una serie de ordenanzas municipales trataran de dificultarles el ejercicio de su profesión, como la prohibición de trabajar en domingo o en días festivos cristianos, el vender fuera de la judería o el trabajo clandestino, etc., medidas que en la práctica obtuvieron escasos resultados. Y es que muchos de los artesanos judíos eran excelentes profesionales en su especialidad, en particular orfebres y sastres. Las conversiones forzosas de los judíos en 1391 resolvieron en parte el problema de esta competencia, pero crearon otro para los clientes, que fue el abuso de algunos profesionales cristianos con su monopolio de la actividad. Tenemos el ejemplo de Orihuela, cuyo Consell municipal se negaba en marzo de 1416 a crear una judería nueva. En octubre de 1417 los jurados trataron de ver si se podía hacer

37. Hinojosa Montalvo, J., «El préstamo judío en la ciudad de Valencia en la segunda mitad del siglo XIV», en Sefarad, XLV, Madrid, 1985, pp. 315-339; Magdalena Nom De Deu, J. R., «Juramentos de prestamistas y corredores judíos en Castellón de la Plana (1441-1448)», en Anuario de Filología, 3 (Barcelona 1977), pps. 215-223; Magdalena Nom De Deu, J. R., Judios y cristianos ante la «Cort del Justicia» de Castellón, Castellón, 1988; Mira JóDAR, A. J., «Els diners dels jueus». Activitats econòmiques d'una familia hebrea al mon rural Valencià», en Revista d'Història Medieval, 4, (1993), pp. 101-127.. 
una judería en la villa. La razón alegada: porque los sastres habían aumentado el precio de las ropas que cortaban y, aunque no se dijera explícitamente, se consideraba muy beneficioso que de nuevo volviera a haber sastres judíos que acabara con estos abusos ${ }^{38}$.

Una actividad que podemos considerar específica de los judíos asentados en las localidades meridionales del reino de Valencia fue la actuar como intérpretes o torcimanys al servicio de la Corona, gracias a su conocimiento de la lengua árabe, que durante el siglo XIII les había permitido actuar como traductores al servicio de la Corona en actos de rendición de plazas por los musulmanes andalusíes, o como embajadores o diplomáticos ante los sultanatos del norte de África $^{39}$. Es así, como en 1264 vemos actuar En Elche como intérprete al destacado judío Astruch Bonsenyor en las negociaciones que precedieron a la entrega de la plaza a Jaime I por los mudéjares rebeldes a la autoridad de Alfonso X de Casti1la. Y fue a este judío a quien se encomendó el reparto de tierras y heredades de Elche, junto con tres cristianos ${ }^{40}$.

Fue durante el reinado de Jaime II, en las últimas décadas del siglo XIII y primeras del XIV, cuando fue más activa esta actividad de los judíos como trujamanes en las comarcas recién incorporadas al reino de Valencia, una zona de mayoritaria población mudéjar, y en 1306, por ejemplo, vemos al rey de Aragón conceder a perpetuidad y libres de todo servicio, a petición de don Juan Manuel, al judío Isaac Abennatara, intérprete del infante, una serie de casas y tierras en Elche, que fueron del musulmán Cid Abenabenadrón.

En enero de 1308 Alfonso Guillém era nombrado secretario real, cargo desempeñado hasta entonces en Elche por Isaac Vidal, y cuyo trabajo consistía en pasar a limpio los libros escritos en árabe - «en morisch»-de los colectores de las rentas en el territorio de Elche, y D. Romano ha publicado el texto de 1314 que trata de la discusión habida entre los mudéjares de Elche y el recaudador Alfonso Guillém, siendo precisa la intervención del trujamán que estaba al servicio del baile de Elche, Abraham al-Behbehí, para que lo tradujera del árabe al catalán ${ }^{41}$.

38. El 3 de octubre de este año 1417 el Consell ordenó que se pregonara que ningún sastre de la villa y su término osara cortar ropas sin haberla pesada antes y después, sin cometer fraude, bajo la pena de 60 sueldos. A.M.O. M. C. $\mathrm{n}^{\circ} 210$, fol. $181 \mathrm{r}$.

39. Romano, D., «Judíos escribanos y trujamanes de árabe en la Corona de Aragón (reinados de Jaime I a Jaime II)», en Sefarad, XXXVIII (1978), pp. 71-106. Los funcionarios judios de Pedro el Grande de Aragón, Barcelona, CSIC, 1970.

40. Ibarra Ruiz, P., Historia de Elche, Alicante, 1895, p. 44. Hinojosa Montalvo, J., Los judios en Elche, p. 792.

41. Romano, D., «Judios escribanos y trujamanes de árabe en la Corona de Aragón (reinados de Jaime I a Jaime II)», en Sefarad, XXXVIII (1978), pp. 71-104; Romano, D., Un texto en aljamia hebraico-árabe (Elche, 1314), en Sefarad, 29, (1969), pp. 313-318. Hinojosa Montalvo, J., Los judíos en Elche, p. 795. 
Otros judíos trabajaron en la misma tarea pero al servicio de la administración real, la bailía general de Orihuela, como hizo en 1318 Jucef Cap de Pebre, que cobró 100 sueldos «per treballs que ha sostenguts per co com és stat torcimany en moles feyts de la batlia, e special ab los moros de Crivillén».

Algunos judíos destacaron a nivel personal por sus conocimientos especializados, como fue el ejercicio de la medicina. Desde la conquista de Jaime I encontramos a médicos reales judíos o alfaquines, que ejercieron un papel importante en la corte real aragonesa en el siglo XIII en tiempos de Jaime I y su hijo Pedro el Grande, siendo algunos de ellos beneficiados con donaciones en el reino de Valencia. Es precisamente la capital del reino donde se concentraba el mayor número de médicos y cirujanos, en razón de la importancia numérica de su aljama, tal como hemos puesto de relieve en un reciente estudio ${ }^{42}$.

Recordemos que el mundo de la sanidad no era sólo patrimonio de los hombres, sino que también encontramos alguna mujer en esta actividad, como vemos en el permiso especial concedido por Alfonso IV antes de 1332 a Adefa, judía de Valencia, para que, con el fin de poder sustentarse, pudiera ejercer durante un año como médico de los ojos, es decir oftalmóloga, en la ciudad de Valencia y en las tierras de jurisdicción real ${ }^{43}$. No abundaron las mujeres cirujano y en este sentido es muy ilustrativo el caso de doña Yamila, viuda de don Yuçaf, cirujano, a la que los jurados oriolanos autorizaron el 13 de agosto de 1371 a utilizar el arte de silugía, ya que había hecho muchas y buenas curas, según certificaban muchos hombres buenos. Dos maestres judíos y dos cristianos la examinaron en medicina y cirugía y le concedieron el certificado de aptitud.

La medicina en el mundo medieval era muy deficiente, en particular en los pequeños o medianos núcleos urbanos, como era el caso de Elche, donde no había médico, y con frecuencia había que recurrir a profesionales hebreos, de reconocido prestigio. En 1370 el Consell contrató a maestre Hagim (metge fisich), para que ejerciera como médico del lugar, con un salario anual de 200 sueldos durante el tiempo que los jurados estimaran oportuno, debiendo residir personalmente y pudiendo rescindírsele el contrato cuando no se le considere apto. De nuevo en 1382 las autoridades ilicitanas subvencionaron con los 200 sueldos y casa a un judío, barbero y sangrador, entendido en la materia y de reputada fama para atender las necesidades sanitarias locales ${ }^{44}$.

\footnotetext{
42. Hinojosa Montalvo, J., «Médicos judíos en la ciudad de Valencia durante la baja Edad Media (siglos XiII y XIV)», en Estudos em homenagem ao Profesor Doctor Jose Marques. Porto, Faculdade de Letras-Universidade do Porto, 2006, pp. 415-436.

43. A.C.A. C, reg. 484. fol. 110 r. 31-1-1332, Valencia. Este permiso debería respetarlo el justicia de Valencia y los oficiales reales.

44. Hinojosa Montalvo, José, Los judíos en Elche..., p. 799.
} 
La situación se mantuvo hasta 1391, en que muchos médicos se hicieron cristianos a la fuerza, como el caso del célebre Humer Tahuell, de Valencia, que durante el motín se refugió en casa de unos destacados personajes de la ciudad, de donde fue sacado a la fuerza para ser bautizado, tomando el nombre de Pere d'Artés. Unos se quedaron en las localidades donde residían y siguieron ejerciendo su profesión, ahora con plenitud de derechos, dado que oficialmente eran ya cristianos. Es lo que sucedió, por ejemplo, en Valencia, donde un alto porcentaje de los médicos durante el siglo xv tenía un origen judío ${ }^{45}$. Otros prefirieron el camino del exilio, contando en algún caso con salvoconductos reales y cartas de recomendación para su nuevo destino. Es lo que sucedió con el médico mestre Vidal Gracia, quizá oriundo de Barcelona, que en 1391 trabajaba en Burriana. Se convirtió al cristianismo y adoptó el nombre de Gracia de Ribes. Debió gozar de fama por sus conocimientos médicos, pues en 1390 Juan I le concedió privilegios especiales, así como a su hijo Lobell, que era médico de la aljama vecina de Castellón. Padre e hijo, junto con sus familiares y domésticos, se beneficiarían de cuantas gracias, honores, libertades, inmunidades y prerrogativas gozaban los domésticos y familiares de la casa real, lo que explica que el 15 de enero de 1393 Juan I extendiera un salvoconducto a su favor, junto con Gracia de Heredia y Llop Gracia, sus hijos, así como sus familiares, totalizando dieciséis personas, todos conversos, para poder ir con sus cabalgaduras, bienes, joyas y demás impedimenta hacia Foix, para cuidar a la infanta doña Juana, hija del monarca aragonés ${ }^{46}$.

Otra profesión considerada como tradicional entre los judíos era la de recaudadores de impuestos en algunas localidades, en particular las de señorío, como fue Elche. Aquí ya en fecha temprana encontramos a Mossé Abenxuxén, recaudador de las rentas de don Juan Manuel, señor de la villa. Un siglo más tarde, en 1380 , se documenta a Isaac Cap como colector de las rentas señoriales, puesto desempeñado en 1381 por Ahrahim Abenbahe. En ocasiones los vemos actuar como mensajeros del Consell, y en 1382 vemos al citado Abrahim Abenbahe, que por entonces se movía muy bien en los entresijos del poder local y señorial, antes de ir a la corte del infante don Martín, ofrecer sus servicios a los jurados, quienes le entregaron una carta con asuntos relativos a las imposiciones de la villa y a la inquisición, junto con 300 florines solicitados por el señor. En el valle

45. García Ballester, L., «La desintegración de la medicina de la minoría judía en la Valencia bajomedieval», en III congreso Nacional de Historia de la Medicina, Valencia, 1969, II, pp. 31-35; García Ballester, L., La medicina a la València medieval: Medicina i societat en un país medieval mediterrani, Valencia, 1989.

46. Magdalena Nom De Deu, J. R., La aljama de judios de Burriana (s. XIII-XV), Burriana, 1978; Hinojosa Montalvo, J., The Jews in the Kingdoom of Valencia. From the Progroms to the Expulsion, (1391-1492), Jerusalem, Hispania Judaica, 1993; Hinojosa Montalvo, J., Los judios en tierras valencianas, Valencia, Institució Alfons el Magnànim, 1999. 
de Elda en 1355 vemos a Jafudá Francés como colector de las rentas de la villa y de la pecha de los moros.

También los encontramos como arrendadores de rentas reales, municipales, señoriales o eclesiásticas, aunque hay que decir que en el reino de Valencia siempre desempeñaron un papel secundario en este terreno, con algunas excepciones a nivel local. Ejemplos de estos arrendadores los tenemos en el Alicante de 1391, en que el judío Samuel Rondi arrendando el derecho de aduana, mientras que en los años setenta Mossé Almateri arrendaba el derecho del almojarifazgo en Orihuela. $\mathrm{O}$ en Castellón, donde Abraham Legem se asoció con cristianos en operaciones especulativas de riesgo, como el arriendo en 1435, junto a los mercaderes Jaume Mas y Pere Castell, del tercio diezmo por una suma superior a los 6.700 sueldos $^{47}$. También Abraham Caxo fue arrendador entre 1468 y 1476, al menos, arrendó los derechos del tercio-diezmo en Burriana y sus alquerías del Palau Lombart y de Alcaramit.

Pero si hubo alguna actividad que identificara a los judíos ésta fue la de prestamista, hasta el punto de que judío y usurero se hicieron sinónimos. El tema ha sido objeto de estudio en los últimos años y es bastante bien conocido a nivel de Valencia, Castellón y otras localidades del reino ${ }^{48}$. La normativa que aparece en los Furs valencianos sobre la usura es muy similar a la que existía en Cataluña y Aragón, que aparece bien recopilada en todos los estudios clásicos sobre los judíos de la península ibérica. Resumiendo su contenido y las líneas maestras recordemos que Jaime I, presionado por las disposiciones conciliares, a partir de 1228 reguló minuciosamente el préstamo judío, quedando fijado el interés en cuatro dineros

47. Mira JódAR, A. J., Els diners dels jueus, p. 112.

48. Furió, A., «Diners i crèdit. Els jueus d'Alzira en la segona meitat del segle XIV», en Revista d'Història Medieval, 4 (1993), pp. 127-160; García Marsilla, J. V., Vivir a crédito en la Valencia medieval. De los orígenes del sistema censal al endeudamiento del municipio, Valencia, Universitat, 2002; Hinojosa Montalvo, J., «El préstamo judío en la ciudad de Valencia en la segunda mitad del siglo XIV», en Sefarad, XLV (1985), pp. 315-339; Hinojosa Montalvo, J., «La comunidad hebrea en Valencia: del esplendor a la nada (1377-1391)», en Saitabi, XXXI, Valencia, 1981, pp. 47-72; «Actividades de los judíos valencianos en el siglo XIV», En la España Medieval. La ciudad hispánica durante los siglos XIII al XVI, Madrid, 1985, II, pp. 1547-1566; Los judios en tierras valencianas, Valencia, Institució Alfons el Magnànim, 1999; La judería de Xàtiva en la Edad Media, Xàtiva, Ajuntament, 1999. Premi d'Investigació Històrica «Sarthou Carreres», 1998; Mira JódAr, J.A., «Els diners dels jueus. Activitats econòmiques d'una familia hebrea al món rural valencià», en Revista d'Història Medieval, 4 (1993), pp. 101-127; Magdalena Nom De Deu, J. R., «Juramentos de prestamistas y corredores judíos en Castellón de la Plana (1441-1448)», en Anuario de Filología, 3 (Barcelona 1977), pps. 215-223; Judios y cristianos ante la «Cort del justicia» de Castellón, Castellón de la Plana, 1988; Magdalena Nom De Deu, J. R. y Piles Ros, L., «Prestamistas y corredores judíos de Valencia en 1342», en Miscelánea Homenaje a José María Doñate Sebastiá, Vila-real, Ajuntament, 1993, pp. 239-253; Tolosa, L., «Usureros judíos en la Valencia del siglo XIV», en Ir Col·loqui d'Història dels Jueus de la Corona d'Aragó, Lleida, 1991, pp. 291-301. 
por libra (20\%) y la obligación del hebreo de prestar juramento ante el oficial real de su ciudad, que en el caso de Valencia, como vemos, era el justicia.

En la ciudad de Valencia, la mejor estudiada, la cifra anual de prestamistas se sitúa entre 120 y 150 personas, de las cuales bastantes se repiten en varios años, aunque predominan los que ejercían la usura de forma ocasional, sólo un año. A partir de 1391 y el asalto a la judería prácticamente desaparecieron los prestamistas judíos, como resultado de la conversión forzosa al cristianismo. Los conversos ya no podrán dedicarse a la usura, y su lugar fue ocupado por el mercado de los censales y violarios. Oscilando entre un 67,9 y un $81,4 \%$ la presencia masculina era predominante en estas actividades crediticias, siendo de destacar el elevado número de mujeres -un $25,8 \%$ en el volumen global- que realizaban prácticas usurarias. En cuanto a la clientela de estos prestamistas los agricultores eran mayoría sobre las demás profesiones, seguidos por gentes del sector secundario y terciario, sobre todo de la manufactura textil. Mención aparte merecen los préstamos contratados por las corporaciones municipales con judíos, destacando en el caso de Valencia el caso de Jafudà Alanzar, que acaparó los préstamos en las décadas 50, 60 y 70 del siglo XIV, igual que hizo con la Corona, atenazada por las deudas generadas por la guerra con Castilla. En ocasiones extremas se acudía a prestamistas foráneos, como en 1334, en que los jurados escribieron a Ismael de Oblites, un judío de la localidad navarra de Tudela, pidiéndole que atendiera sus necesidades de dinero y les prestara nada menos que 200.000 sueldos, lo que indica que nadie en Valencia era capaz de asumir una empresa de esta envergadura. Como mensajero para recibir el dinero fue Berenguer de Codinachs, jurado, sin que sepamos ni el motivo del préstamo -quizá relacionado con la campaña del Estrecho- ni más detalles ${ }^{49}$. En cuanto radio de acción de estos usureros judíos se observa una uniformidad en su radio de acción, que es de unos 30 o 40 kilómetros, correspondiendo al emplazamiento de las principales juderías. En general se trataba de un préstamo a corto plazo, de unas decenas de sueldos, que oscilaba entre seis meses -alguno menos tiempo- y un año, unos préstamos que permitían mantenerse la empresa familiar, campesina o artesana.

\section{LAS RELACIONES CON LA CORONA Y LOS CRISTIANOS}

Es habitual a estudiar a los judíos peninsulares en sí mismos, como un ente propio y aislado, como si hubieran vivido encerrados siempre en sus juderías, marginados y sin contactos exteriores. Pero el judío formaba parte de una sociedad minoritaria en el seno de una sociedad cristiana mayoritaria, que imponía sus normas y regulaba estrictamente los contactos entre judíos y cristianos. El judío

49. A.M.V. Lletres misives, g3-1, fol. 27 v. 
necesitaba relacionarse con la sociedad cristiana circundante, a la vez que trataba de conservar sus peculiaridades, generando unas relaciones mucho más amplias y variadas de lo que pudiera pensarse si sólo nos atuviéramos a las frías pragmáticas eclesiásticas y reales, o a los acuerdos municipales y de Cortes, llenos de prohibiciones de contactos entre cristianos, judíos y musulmanes.

Los judíos dependían directamente de la Corona, que los consideraba «nostre tresor», una permanente fuente de ingresos, sin que tuvieran derechos políticos ni representación en las Cortes del reino. Pero esta dependencia del rey tenía sus ventajas, pues era la salvaguarda de sus derechos, siempre que se supediten a las normas de la Iglesia y del Estado. Nos encontramos, por tanto, con una clara situación de inferioridad respecto a la sociedad dominante, la cristiana, plasmada en una serie de medidas discriminatorias.

El judío carecía de cualquier derecho o participación política «per se» y era visto como un elemento ajeno a la sociedad cristiana, y los asuntos concernientes a sus relaciones con los cristianos eran tratados por éstos en las reuniones de Corts. ¿Qué temas y en qué porcentaje se trataron en las Corts valencianas durante estos siglos? En el caso valenciano la casuística fue grandes, desde el controvertido y candente temas de las usuras y los abusos en la percepción de los intereses hasta las relaciones de los judíos con los oficiales reales, como en las de 1342, donde se trató el tema de la jurisdicción de Valencia y del baile general del reino sobre los judíos, en particular en los temas referentes a la jurisdicción civil y criminal del baile general, así como la exclusión de otros oficiales reales en los asuntos civiles o criminales de las aljamas judías.

También fue objeto de preocupación de las Cortes lo referente a los juramentos mixtos, judío-cristianos, donde los judíos resultaban humillados por las fórmulas que se les obligaba jurar, o los referentes al testimonio prestado por el cristiano contra el judío. A ello se añadían una extensa panoplia de medidas de segregación y de discriminación contra el judío, igual que sucedía en la Corona de Castilla, en particular normas sobre el vestido (obligación de llevar una señal distintiva en el mismo cuando se estaba fuera de la judería) o la prohibición absoluta de relaciones sexuales con los cristianos, tendentes a evitar el contacto entre ambos grupos, cualquier posible contaminación, a la vez que les recordaba su situación de inferioridad en los reinos cristianos. Estas medidas segregacionistas también eran apoyadas por los rabinos, ya que ayudaban al pueblo judío a mantener su cohesión y sus señas de identidad, y también se reflejó en el marco espacial, como en las Cortes de 1369-1371, en que los representantes del brazo real pidieron al rey que los judíos de Valencia, que habían salido fuera del recinto de la judería, debido a su crecimiento, regresaran a sus anteriores límites. En cualquier caso, los judíos valencianos sólo fueron objeto de atención especial en 
las Cortes valencianas y en ningún momento hubo un «problema judío», como se aprecia en las Cortes de Castilla y León durante los siglos bajo-medievales ${ }^{50}$.

El judío vivía segregado y discriminado con respecto a los cristianos, igual que el mudéjar. Se le toleraba la práctica de su religión porque se le consideraba útil y se pensaba que algún día abandonaría su ceguera y aceptaría la venida del Mesías, y ello a cambio de toda una panoplia de medidas legales discriminatorias, dispuestas a recordarle su inferioridad. Tales medidas segregatorias se remontaban ya al siglo IV y v, pero fue, sobre todo, a partir del IV Concilio de Letrán (1215) cuando la Iglesia presionó a los príncipes cristianos para su aplicación: segregación espacial, es decir reclusión en barrios específicos, las juderías, algo habitual en el reino de Valencia en los siglos medievales. Valga como ejemplo la disposición dada por Alfonso IV en 1329 en relación con los judíos de Orihuela, prohibiendo que vivieran cristianos en su judería seu habitaciones, y la venta de casas judías a cristianos, debiendo ser devueltas las ya vendidas. Al fin y al cabo no era más que la aplicación de las directrices emanadas desde Roma hacía algo más de un siglo y continuamente recordadas a los gobernantes.

La segregación afectó también al terreno de lo personal, intentando prohibir todo contacto entre miembros de las dos religiones, sobre todo los sexuales, castigados con las penas más rigurosas por los Furs; segregación en el marco laboral, con medidas restrictivas en el espacio y el tiempo para el desarrollo de sus actividades profesionales; segregación judicial y fiscal; sin olvidar, la discriminación que suponía la obligación de llevar signos distintivos específicos, que acreditaran la condición de judío, fuera del marco de la judería.

Las específicas normas alimenticias de los judíos -igual que las de los mudéjares-generaron toda una casuística legal y práctica para impedir los contactos entre miembros de las diferentes religiones, lo que no siempre se cumplía, por las más variadas razones. Como ejemplo de esta intransigencia y desprecio tenemos el rechazo de los cristianos de Elche en 1312, a que los hebreos de la villa degollaran los animales según su ritual en las carnicerías de los cristianos, temerosos de que las carnes que consumían resultasen contaminadas, postura similar a la que mantenían moros y judíos con respecto o los cristianos. La intransigencia no es patrimonio de un determinado pueblo o religión. Si en principio el rey dispuso que pudieran matar dos reses diarias para su consumo, desde 1314 los judíos ilicitanos tuvieron su propia carnicería.

Otras veces, cuando no se podía impedir que tuvieran su propia carnicería, lo que hacían las autoridades era que los carniceros cristianos vendieran animales a los judíos. Es lo que sucedió en Valencia a comienzos de 1381, fecha en que la

50. Hinojosa Montalvo, J., «Les Corts i les minories religioses: els jueus», en Les Corts forals valencianes. Poder i representació, Valencia, 1994, pp. 136-138. 
aljama de la ciudad expuso al rey que ellos tenían la carnicería propia donde sacrificaban los animales según el rito judío, pero ahora el almotacén y los jurados dieron orden de que ningún carnicero de la ciudad y su término vendiera terneras y ovejas a carniceros judíos, bajo la pena de confiscación del animal y 60 suel$\operatorname{dos}^{51}$. El monarca declaró en suspenso dicha orden, pero parece que los jurados no la cumplieron de forma estricta, pues en los cuadernos del justicia civil no es raro encontrar en estos años multas a carniceros que han intentado burlar dicha ordenanza municipal.

Con tal panorama, mal se puede hablar de convivencia entre las tres religiones en la España medieval, debiendo sustituir este término por el de coexistencia. Hubo tolerancia, pero basada en la conveniencia, sobre todo económica, más que en razones éticas, ya que tales conceptos, vigentes en nuestra sociedad en el siglo XXI, eran desconocidos para el hombre medieval. La tolerancia en la Edad Media nada tiene que ver con lo que hoy entendemos bajo este concepto, el de libertad religiosa, ya que como Joseph Pérez:

«La libertad religiosa es una conquista de la historia, un fenómeno reciente (...) se tardará mucho tiempo para que se pase de la afirmación de los derechos de la verdad a la afirmación del derecho del error. Ni siquiera hoy están todos convencidos de ello. Creo, pues, que sería ilusorio hablar de una España medieval que tuviera diez siglos de adelanto sobre la evolución del mundo» ${ }^{52}$.

Es evidente que existe una discriminación y segregación hacia el judío, un odio, de base religiosa y económica (la usura), pero también que hubo puntos de contacto, de aproximación entre cristianos y judíos, de relaciones cotidianas, que muestran como el judío estaba bien integrado en la formación social de la época.

La inferioridad legal del judío con respecto al cristiano le prohibía ser funcionario, tener autoridad sobre el cristiano, ser médico de cristianos, etc. pero una cosa era la teoría y otra la realidad de cada día, y hemos visto como Jaime I utilizó a los judíos como funcionarios, como bailes, en el reino de Valencia durante su reinado. Y otro tanto sucede en el terreno de la medicina, donde desde papas a soberanos utilizaban los servicios de médicos judíos. Y lo mismo los municipios y los particulares, dado que su preparación científica los hacía imprescindibles, sobre todo en las pequeñas poblaciones, donde no había cristianos preparados, como era el caso de Elche, al que luego me referiré.

Las relaciones con los cristianos se hizo realidad, sobre todo, en el mundo laboral, a través de los contactos cotidianos en el mercado y las ferias, en la com-

51. A.C.A. C. reg. 1273, fol. 5 r-v. 18-3-1381, Zaragoza.

52. PÉREZ, J., «Mozárabes y mudéjares en la España medieval», en Proyección histórica de España en sus tres culturas: Castilla y León, América y el Mediterráneo, Valladolid, 1993, I, p. 242. 
pra y venta de mercancías en las tiendas de unos y otros, en el nombramiento de procuradores cristianos por parte de los judíos, en la formación, en ocasiones, de compañías mixtas, de cristiano y judío. Así mismo los artesanos judíos, sastres, orfebres, etc., tenían buena parte de su clientela entre los cristianos, dada su eficiencia profesional, y los judíos no dudaban en acudir a los notarios cristianos para redactar sus contratos, procuraciones e incluso testamentos. Por supuesto que fue el marco de la circulación del dinero el que generó unas relaciones más intensas entre cristianos y judíos. Me refiero al préstamo con interés, al logro o usura, que controlaban los judíos, dada la prohibición eclesiástica que recaía sobre los cristianos de prestar dinero con interés. El tema de la usura fue el que más hizo crecer el antijudaísmo durante el siglo xIv, azuzado por las predicaciones de los frailes, y, sin duda, estuvo en la base de la violencia cataclísmica de 1391.

Había también otra violencia cotidiana, la de los insultos y el desprecio de los cristianos, o la que cristalizaba durante la Semana Santa, ya que los judíos eran el pueblo deicida, el causante de la muerte en la cruz de Jesucristo. Tales violencias eran contenidas habitualmente por las autoridades locales, que cobraban a los judíos un impuesto especial en estas fiestas, el dret de protecció, colocando guardias armados a la entrada de la judería para evitar su asalto por los cristianos. Apedrear judíos formaba parte de la diversión de los cristianos, en particular niños y mozalbetes, en la Semana Santa.

En una judería pequeña, como la de Castellón, por citar un ejemplo, parece que las cosas discurrieron dentro del cauce de la normalidad en el siglo xv, al menos no hay noticias de estos actos violentos hasta el año 1473. En el mes de mayo Mossé Mayor, adelantado de la judería, se quejó al baile general del reino, porque el baile de la villa, Bertomeu de Bues, los había agraviado, ya que les obligó a pagar al lugarteniente del Justicia una cantidad de dinero para protegerlos el jueves, viernes y sábado santo, pero en lugar de hacerlo los hauria apedregat e fet aperegar esos días, por lo que consideraban que quedaban exentos de dicho pago. No quedaron ahí los abusos, pues el citado oficial multó a un adelantado con cien morabatines y a otro lo encarceló, amenazando a la aljama con embargos, razones por las que el baile general le citaba el 20 de mayo ante su corte para escuchar las alegaciones que creyera oportuno presentar a tales quejas $^{53}$.

No es cuestión de extendernos en detalle en la variada gama de situaciones que la vida diaria ofrecía para el contacto de gentes de uno y otro credo, como era el caso de las relaciones sexuales, duramente perseguidas por las autoridades, pero que, sin embargo, eran una realidad, ejercida habitualmente por la vía de 
la prostitución y el burdel, así como de forma más o menos clandestina. El juego era otro de los marcos de solidaridad y tanto cristianos como judíos sentían pasión por el juego, y cualquier población importante tenía su tahurería con las tablas para el juego, fuente de ingresos para las haciendas locales y real. Además, se jugaba dados, gresca, naipes, etc., en cualquier lugar abierto o cerrado, fomentando el contacto entre gentes de ambas religiones, aunque ello tenía sus riesgos, pues a menudo las diferencias por el juego acababan en insultos, peleas y blasfemias, lo que llevó a las autoridades municipales y reales a restringir la presencia de judíos en los ámbitos privativos de los cristianos, algo que también era mal visto por los rabinos, celosos defensores de la ortodoxia judía y de mantener la separación con los cristianos, de evitar cualquier contacto que pudiera contaminarlos en su espiritualidad.

Como ejemplo de lo dicho tenemos la ordenanza dada en 1380 los jurados de Elche prohibiendo el juego de dados, gresca e taules en la villa, salvo en la tahurería, a causa de las riñas entre cristianos y judíos, en tanto que el baile local les acusaba de malhablados y alguno de ellos era reprendido públicamente por los jurados. Los judíos se defendieron contra las calumnias y difamaciones exigiendo certificados de buena conducta a las autoridades.

Los judíos fueron una minoría que podemos calificar de «privilegiadas», pues la abundante concesión de privilegios por parte de la Corona fue una característica general durante estos siglos medievales. Privilegios que podían ser generales o particulares. Los primeros eran los otorgados a toda la comunidad judía de una localidad, e incluso a todos los judíos del reino, pues no debemos olvidar que los judíos dependían directamente de los monarcas cristianos, eran propiedad personal del rey y como tales pertenecían al patrimonio real. No pertenecían al reino, en ninguna de cuyas instituciones participaban. La institución monárquica era la única que dispensaba sus derechos constitucionales y privilegios, pudiendo derogarlos o ampliarlos a su arbitrio ${ }^{54}$.

El rey, en la práctica, ejercía el control de las aljamas de su señorío a través de la legislación real, en la que se incluyen los privilegios y la emanada de las Cortes, dado que las aljamas eran patrimonio real. Entre los privilegios generales concedidos a la aljama judía de Orihuela para su restauración tras la guerra de los dos Pedros figura el dado en octubre de 1387, según el cual cuando la aljama tuviera que enviar mensajeros a la corte para resolver asuntos propios, en lugar de tener que enviar dos mensajeros podría mandar sólo uno. Otro de los privilegios de los que disfrutaban las aljamas era la posibilidad de lanzar las penas de excomunión mayor o menor contra los transgresores de la Ley, en particular contra

54. Hinojosa Montalvo, J., «Privilegios reales a mudéjares y judíos», en Los cimientos del Estado en la Edad Media, Alicante, Marfil, 2004, pp. 279-308. 
los malsines, que tanto daño podían hacer a la comunidad con sus calumnias y falsas acusaciones.

En otros casos el privilegio real era concedido a un particular, como hizo el 12 de enero de 1360 la reina Leonor, tutora del infante Martín, señor de Elche, quien en agradecimiento a los servicios prestados por el judío Jucef Abentaurell, de su casa y de la del infante, le enfranqueció, a voluntad, de todo servicio que debiera prestarle a ambos por una caballería y dos peonadas que tenía en el lugar de Bemboch. También del pago del derecho de almagram y de la pecha anual por dichas heredades y del agua que tenía en la huerta de la villa.

Otros privilegios eran de carácter fiscal, concediendo exenciones tributarias a un determinado individuo, o privilegios para viajar e instalarse en otro lugar o territorio, privilegios para llevar armas prohibidas o no llevar la señal infamante de la rueda amarilla en el vestido cuando iban por los caminos. No faltaron los privilegios y franquicias económicas por parte de la Corona o de los municipios. Es el caso, por ejemplo, de Abraham Ageme, judío de Orihuela, que el 3 de enero de 1481 nombró procurador a Joan Quexans, para, entre otras cosas, presentar el privilegio de franquicia que tenía por la ciudad de Orihuela y ahorrarse el pago de los derechos reales ${ }^{55}$. 